\title{
The trace aminergic system: a gender-sensitive therapeutic target for IBS?
}

\author{
Lesha Pretorius (D) and Carine Smith * (1)
}

\begin{abstract}
Due to a lack of specific or sensitive biomarkers, drug discovery advances have been limited for individuals suffering from irritable bowel syndrome (IBS). While current therapies provide symptomatic relief, inflammation itself is relatively neglected, despite the presence of chronic immune activation and innate immune system dysfunction. Moreover, considering the microgenderome concept, gender is a significant aetiological risk factor. We believe that we have pinpointed a "missing link" that connects gender, dysbiosis, diet, and inflammation in the context of IBS, which may be manipulated as therapeutic target. The trace aminergic system is conveniently positioned at the interface of the gut microbiome, dietary nutrients and by-products, and mucosal immunity. Almost all leukocyte populations express trace amine associated receptors and significant amounts of trace amines originate from both food and the gut microbiota. Additionally, although IBS-specific data are sparse, existing data supports an interpretation in favour of a gender dependence in trace aminergic signalling. As such, trace aminergic signalling may be altered by fluctuations of especially female reproductive hormones. Utilizing a multidisciplinary approach, this review discusses potential mechanisms of actions, which include hyperreactivity of the immune system and aberrant serotonin signalling, and links outcomes to the symptomology clinically prevalent in IBS. Taken together, it is feasible that the additional level of regulation by the trace aminergic system in IBS has been overlooked, until now. As such, we suggest that components of the trace aminergic system be considered targets for future therapeutic action, with the specific focus of reducing oxidative stress and inflammation.
\end{abstract}

Keywords: Trace amine, Gut microbiome, Inflammation, Oxidative stress, Drug discovery

\section{Introduction}

Irritable bowel disease (IBS) is a functional gastrointestinal disorder, which is prevalent in more than $10 \%$ of the global population [72]. Although IBS is easily recognised (recurrent abdominal pain associated with change in stool consistency and frequency, as is the case in inflammatory bowel disorder (IBD) [16], but in the absence of structural abnormalities [121]), there is still a lack of any sensitive or specific biomarkers [194], limiting advancement in terms of drug discovery for treatment of this debilitating condition.

*Correspondence: csmith@sun.ac.za

Department of Physiological Sciences, Stellenbosch University,

Stellenbosch Private Bag X1, Stellenbosch 7062, South Africa
It is important to note that epidemiological studies have consistently shown female predominance for IBS in both non-patient and patient populations, with ratios of up to $5: 1$ in tertiary care settings [157]. Furthermore, many women with IBS report gastrointestinal (GI) symptom fluctuation and exaggeration (flares) during pre-menses and pre-menopausal phases [96, 109, 230]. Although, some of these symptoms seem to be common among non-IBS or normally asymptomatic women too $[23,157]$. However, the fact that IBS symptom onset often coincides with gonadal maturation, again implicates hormone levels as confounder in IBS aetiology [97].

In terms of current IBS therapy, treatment strategies range from microbiota-based therapies (probiotics, prebiotics, synbiotics, non-absorbable antibiotics 
and faecal microbiota transplants) to opioid receptor agonist/antagnoists, and dietary interventions, most of which provide symptomatic relief [45]. Of specific interest to this review, present-day strategies seem focused on addressing clinically evident symptoms only, with relative neglect of inflammation, despite the fact that chronic immune activation and innate immune system dysfunction is implicated in IBS pathogenesis [123]. The importance of considering inflammation in IBS, is underlined by several factors. Firstly, a recent review concluded that gender-differences in inflammation-specifically the fact that prognosis in chronic inflammatory conditions are worse in females, in line with the female predominance in IBS - cannot be fully accounted for by hormonal differences between genders [38]. Secondly, psychosocial stress is the most generally recognized risk factor for both development and relapse of IBS [222]. Here again, females are more at risk, with a significant female predominance reported for anxiety and depression-associated disorders [3]. Taken together, it is clear that gender is a significant role player in IBS risk, but that hormone differences alone is probably not the only predictor of outcome.

We believe that we have identified a "missing link" that ties together gender, diet, inflammation and anxiety in the context of IBS, which may be exploited as therapeutic target. The trace aminergic system was first described in non-human mammals, as having a "sexual cue" function. Most trace amine associated receptors associate closely with olfactory neurons, suggesting a pheromone-type function. In line with this, significant gender differences were reported for trace amine levels [126]. Furthermore-and specifically relevant to the review topic and IBS-trace amine synthesis has been reported in human neurons, where it is thought to modulate neuronal signalling $[17,148,177]$, and high levels of trace amines have been found in specific foods, as well as bacterial secretomes [13, 129, 153, 201]. Taken together, it is therefore possible that the trace aminergic system may be an additional level of control/ maladaptation in IBS that has been largely overlooked until now. It is also clear that in order to make advances in terms of therapeutic strategies, or even better understanding of disease aetiology, a multi-disciplinary approach is required.

This review therefore aims to provide an integrated and holistic picture of IBS aetiology, including a critical assessment of current methodologies employed in this context where relevant. Drawing from different disciplines in science, we then provide a comprehensive review of the literature on the trace aminergic system, in support of our hypothesis that this system may be targeted therapeutically in the context of IBS.

\section{The complexity that is IBS}

Given the difficulty of IBS management, it would be foolish to underestimate the complexity of the disease aetiology. For the purpose of the current discussion, in the next few sections, we provide an overview of only the most relevant processes at play.

\section{Oxidative stress and inflammation}

Inflammation and oxidative stress go hand in hand, especially in chronic inflammatory disorders, where the poorer prognosis in females has been specifically linked to greater oxidative damage resulting from inflammation $[1,76]$. While the susceptibility of cells to oxidative stress is largely variable between individuals and specific tissue types, a review by Jones et al. [106] explains that the GI tract (GIT) is a particularly high reactive oxygen species environment. Furthermore, in cancer literature, the presence of estrogen receptors (ERs) are commonly known to render cells more sensitive to oxidative stress via diminished antioxidant activities [22, 150]. Similar results have been observed in IBS patients. For example, in a study including 36 IBS patients, plasma activities of xanthine oxidase and adenosine deaminase, and plasma concentrations of malondialdehyde (MDA) and nitric oxide, were significantly higher in patients than controls, while superoxide dismutase, catalase and glutathione peroxidase activities were significantly lower [147]. These results suggest that altered oxidant-antioxidant responses are prevalent in patients with IBS. While both males and females formed part of the study, no analysis in gender differences was performed. Furthermore, increased oxidative stress-related markers (elevated MDA, decreased total antioxidant capacity) were reported in 90 IBS patients more recently [44], with a tendency for female patients to have a worse redox profile [43]. Together, these data suggest oxidative damage to be a major contributor to female predominance of IBS.

Of course, plasma redox status is not necessarily an accurate indication of the status at tissue level. Although clinical evidence of oxidative stress within the intestinal wall is lacking, studies in rodent models of IBS have reported evidence suggestive of oxidative stress in the intestinal wall as well. For example, the total antioxidant capacity (measured by FRAP) of large intestine homogenates of rats (IBS induced by restraint-stress) was significantly reduced compared to controls [156, 244]. Moreover, Mozaffari et al. [156] reported significant increases myeloperoxidase activity and lipid peroxidation in the same homogenates. These reductions in anti-oxidant capacity reportedly correlated with gastrointestinal symptomology as well. While similar studies in humans are lacking, it has been reported that neutrophil counts in colonic biopsies of patients with IBS are significantly 
increased compared to control [39], which may in turn result in increased myeloperoxidase levels, for example, in the colon tissue. Additionally, a very recent study utilising confocal laser endomicroscopy, reported that patients with IBS have a six-fold higher prevalence of colorectal mucosa micro-inflammation than healthy controls [193]. Considering that inflammation and oxidative stress are linked, often occurring in tandem, it is likely that local effects of oxidative damage/stress are implicated in IBS-related gastrointestinal symptomology.

As is the case for many chronic inflammatory diseases, it is difficult to know whether oxidative stress or inflammation manifests first. However, given the selfperpetuating cycle of oxidative stress and inflammation, it is not unexpected that a pro-inflammatory phenotype (increased TNF $\alpha$ and IL-17, decreased IL-10) is prevalent in IBS. Also, in the context of inflammation, a female bias has been reported, with females exhibiting higher inflammatory capacity and generally having poorer prognosis in chronic inflammatory disease [38].

Inflammation is, however, not just an outcome of oxidative stress, but is interconnected with other significant role players in IBS, as demonstrated in the following sections.

\section{Serotonin dysregulation}

Serotonin-or 5-hydroxytryptamine (5-HT) -is a wellknown neurotransmitter and neuro-hormone, which modulates several GI functions, such as motility, visceral sensitivity, immune function and blood flow [113]. Additionally, due to its prominent role in the gut-brain axis, perturbations in 5-HT signalling have also been implicated in the pathophysiology of IBS $[35,45,54,84$, 85, 170, 172]. Mucosal serotonergic enterochromaffin (EC) cells are sensory transducers that respond to luminal stimuli by secreting 5 -HT into the intestinal wall to stimulate the primary afferent nerve fibers of the enteric nervous system [15, 134]. Although relatively rare (less than $1 \%$ of intestinal epithelia), EC cells produce more than $90 \%$ of the body's 5-HT and have been suggested to affect a variety of physiological and pathophysiological states $[84,142]$.

Indeed, in IBS, evidence of dysregulated serotonergic signalling has been established. The most reproducible results indicate that patients with diarrhoea-predominant IBS have higher blood levels of 5-HT [14], while patients with constipation-predominant IBS have lower blood levels of 5-HT $[6,68]$ compared to healthy controls.

Also here, a gender-dependence is evident: $17 \beta$-estradiol (E2) regulates the concentration of $5-\mathrm{HT}$ via two mechanisms. Firstly, E2 increases synthesis of tryptophan hydroxylase [20,21], which is the rate-limiting factor in the conversion of tryptophan to $5-\mathrm{HT}$, thereby increasing the concentration of 5-HT [26, 215]. Secondly, E2 inhibits gene expression of the serotonin reuptake transporter (SERT), and also acts as a SERT antagonist, consequently promoting the actions of 5 -HT by increasing its availability in synapses and interstitial spaces $[168,175]$. Beyond increasing concentration and availability of 5-HT, E2 also modulates the actions of 5-HT. This is because the activation of E2 receptors affects the state and distribution of 5- HT receptors. For example, higher levels of E2 in the presence of progesterone (Prog), upregulates ER $\beta$-resulting in upregulation of the $5-\mathrm{HT}_{2 \mathrm{~A}}$ receptor [169] [117, 155]-and downregulates ER $\alpha$ [41]-resulting in a decreased NFKB-associated activation of $5-\mathrm{HT}_{1 \mathrm{~A}}$ receptors [234]. Therefore, during the reproductive phase of a female lifespan (higher E2 and Prog levels), E2 causes an increase in the density and binding of the $5-\mathrm{HT}_{2 \mathrm{~A}}$ receptor.

It is notable that the $5-\mathrm{HT}_{2 \mathrm{~A}}$ receptor gene is expressed in the brain and the gut [187], and has been reported as the main 5-HT receptor in the perception of pain [219], which may contribute to female bias in pain processing, specifically in an IBS context [146]. Interestingly, a study by Pata et al. [172] implicated $5-\mathrm{HT}_{2 \mathrm{~A}}$ receptor gene polymorphisms as a genetic component of IBS pathophysiology. Specifically, a high incidence of homozygous $C$ allele of the $102 \mathrm{~T} / \mathrm{C}$ polymorphism (also reported in patients with depression and anxiety) and homozygote A allele of the $-1438 \mathrm{G} / \mathrm{A}$ promoter region was reported in patients with IBS. Moreover, the patients with $\mathrm{T} / \mathrm{T}$ genotype had a significantly higher visual analogue score (determines severity of chronic abdominal pain) than patients with other genotypes, suggesting that the $\mathrm{T} / \mathrm{T}$ genotype potentates pain perception, although it is not unique to IBS. It remains to be elucidated if a gender bias exists for this type of mutation. Nevertheless, in line with this data, abdominal pain is a hallmark of IBS and is often a result of colonic distension and visceral hypersensitivity [53]. Of further relevance, it has been reported that $5 \mathrm{HT}_{2 \mathrm{~A}}-1-$ mice had smaller enterocytes, fewer paneth cells, and thinner muscle layers, compared to $5-\mathrm{HT}_{2 \mathrm{~A}}+/+$ littermates [77]. However, since this receptor does not seem to affect colonic transit time, IBS treatments targeting 5-HT receptors have classically focused on $5-\mathrm{HT}_{3}$ (facilitates enteric to central nervous system signalling and promotes gut motility), $5-\mathrm{HT}_{4}$ (augments peristalsis and intestinal secretion), $5-\mathrm{HT}_{1 \mathrm{~B}}$ (initiates peristalsis) receptors [73] and even $5-\mathrm{HT}_{1 \mathrm{~A}} \mathrm{R}-$ for which decreased activity has been linked to exacerbated symptoms of depression [90], a known co-morbidity in IBS. The role of $5 \mathrm{HT}_{2 \mathrm{~A}}$ receptors in the context of IBSrelated pain remains to be fully elucidated. 


\section{Altered colonic ion secretion}

While colonic ion secretion is critically important in maintaining GI motility, there is no concrete evidence that patients with IBS (regardless of the subtype) suffer from primary secretory diathesis [34]. Moreover, it is reasonable to suggest that different IBS subtypes would be characterised by different secretory ion profiles, resulting in either constipation (more common in females) or diarrhoea (more common in males). In terms of a reproductive hormone effect, E2 is a known modulator of ion-secretion, also independent of its effect on 5-HT signalling. Both ER $\alpha$ and ER $\beta$ have been detected in distal colonic crypts [218], where E2 was shown to inhibit epithelial chloride ion secretion in female rats [48], resulting in significant water and salt retention during high estrogen states [165]. Of interest, the gender bias for the anti-secretory action of estrogen was attributed to gender specificity of ion transporter protein expression profiles [48]. Furthermore, E2 reduced currents mediated by the KCNQ1:KCNE3 potassium channel in an Ussing chamber model [4]. Similarly, more recent data shows that E2 links to intracellular calcium, cystic fibrosis transmembrane conductance regulator and $\mathrm{Cl}^{-} / \mathrm{HCO}_{3}{ }^{-}$secretion [239]. Seeing that E2 inhibits colonic chloride ion secretion (consequentially reducing water movement to the lumen), it makes sense that females with IBS generally present with reduced colonic transit/GI motility and constipation, symptoms which alter drastically during menses.

\section{Gut dysbiosis}

Up to now, gender-association has been a continuous thread through all factors contributing to IBS aetiology. However, although it is clear in other disease contexts, e.g. auto-immune disease, that a gender bias indeed also exist in terms of gut microbial content and/or function [191], this association is less clear in IBS, due to a relative lack of research in this context.

Nevertheless, the gut microbiota is widely regarded as a regulatory system that actively mediates numerous physiological functions as part of its symbiotic relationship with its host, via generation of metabolites to affect both nearby and distant organs [137, 231], including the brain [139]. This ability to predict clinical phenotype was even recently suggested to be superior to the predictive power of genetics [197]. Indeed, altered bacterial composition, the so-called dysbiosis, is associated with a spectrum of diseases, including neuropathology and inflammatory conditions [64]. For example, germfree animals demonstrate delayed gastric emptying and intestinal transit, reduced migrating motor complex cycling and propagation, and reduced GABA and VAP33 gene expression, when compared with animals raised in a normal laboratory environment [11]. Thus, it is not surprising that some form of compositional dysbiosis (altered microbial alpha and/or beta diversity) has been implicated as an etiological factor in the development of various gastrointestinal disorders, including IBS [114, $159,171,185]$, where it is thought to drive persistent low-grade inflammation and chronic gut dysfunction [47]. Globally, data on IBS patients suggest reductions in microbial diversity, altered proportions of specific bacterial groups, shifts between mucosal and luminal bacterial abundance [36], and a higher degree of temporal instability of microbiota [64], when compared to healthy individuals.

However, there are several shortcomings of exploring compositional dysbiosis in the context of IBS. Firstly, the compositional alterations reported in the literature are not specific to IBS-similar changes in microbial diversity are found in numerous diseases and conditions [47, 64]. This raises questions regarding their specificity as potential disease biomarkers. Similarly, some authors have criticized whether a relative microbial imbalance that is assessed in a cross-sectional approach, would accurately represent a disease or reflect whether this imbalance occurs secondary to disease-related behaviours (poor lifestyle choices), as this requires analysis of consecutive samples with simultaneous disease variation [71]. Secondly, many of these studies have produced conflicting results within the IBS population [66] for various reasons commonly ascribed to methodology or study design [130, 140, 184, 217]. Thirdly, an improvement in the fairly basic genus-species analysis most often employed [194] is required before significant advances in knowledge gain on the topic are made. This is corroborated by probiotic-focused studies that have emphasized strain-specificity in bacterial function [86], let alone species specificity. Fourthly, the profile of a 'normal' or healthy microbiota is unknown. In our opinion, and those of several other authors, it is impossible to define a healthy microbiome due to the high degree of interindividual variation $[50,58]$, cultural habitual dietary habits and other population-specific factors. This adds to the complexity of selecting suitable controls for gut microbiome studies. Accordingly, extreme care to choose controls similar not only in age and gender, but also cultural background and nutritional habits, is vital to the reliability of any study (but may at the same time also limit its broader relevance). Lastly, efforts to standardize testing, with the introduction of the 'dysbiosis index' [37] has thus far been unsuccessful, since the predictive value of the index was reportedly low and non-specific [71]. Given the fact that compositional analysis does not seem to be sufficiently sophisticated yet to lead to therapeutic advancement in medicine, another option is to 
rather consider functional effects of the total microbiome secretome (i.e. the secretory products of all microbes present in the gut) on its host.

Indeed, another grouping of researchers tends towards analysing functional dysbiosis, or the alterations of the microbial secretomes, in diseased states [59, 104, 192, $242,243,247]$. This is achieved through mass spectrometry or nuclear magnetic resonance techniques, and allows researchers to associate the absence or presence of certain microbial-associated molecules to disease symptomology [224], which may provide an avenue for discovery of disease-specific biomarkers or novel targets for therapeutic treatment [5]. Given the fact that at least some microbial secretory products are competitive survival tactics, the relative absence of a "competing species" may alter secretome content (and thus effect on host cells) significantly, but linearity of secretome change to bacterial predominance cannot be assumed, lending further support for favouring analysis of functional dysbiosis.

In the context of microbiome-associated functional effects, recent studies seem to highlight metabolites derived from microbial transformation of dietary components as having significant effects on several physiological processes [115, 116, 198, 246]. One of the first studies to explore microbial metabolism in the IBS context reported that these patients had increased production of hydrogen gas $\left(\mathrm{H}_{2}\right)$ (fasted breath test) [118]. The authors suggest that the difference in $\mathrm{H}_{2}$ production may be associated with small intestinal bacterial overgrowth (SIBO), since SIBO is common among IBS patients [87] and is associated with higher levels of $\mathrm{H}_{2}$ production in fasted states [112]. Additionally, altered proportions of specific bacterial species, such as decreased Lactobacilli in IBS patients, may alter the amount/distribution of the by-products of microbial metabolism $\left(\mathrm{H}_{2}\right)$. Indeed, Lactobacilli are less gas producing than some other bacteria, such as Clostridia and Enterobacteriaceae [162, 166]. This is confirmed by another study in which colonization by Clostridium spp. was associated with excess gas production, abdominal discomfort and bloating among IBS patients [204]. As such, the relative dysbiosis of IBS patients may result in higher levels of excreted $\mathrm{H}_{2}$ as a functional consequence. Indeed, altered microbial fermentation of carbohydrates results in the excessive production of $\mathrm{H}_{2}$ and methane gases, the elimination of which is essential to maintain efficient fermentation in the gut.

While $\mathrm{H}_{2}$ only represents a single by-product of microbial metabolism, these findings demonstrate the potential of microbial-derived metabolites to alter host functioning. The most obvious example of this lies in the relatively successful use of probiotics as a treatment option for individuals with IBS. Probiotics are "live strains of strictly selected microorganisms which, when administered in adequate amounts, confer a health benefit on the host" [99]. Theoretically, probiotics, primarily those containing Lactobacillus and Bifidobacterium spp., should beneficially modulate the gut microbiota through production of antimicrobial proteins, which should reduce pathogenic bacteria and interfere with epithelial adhesion $[62,78,144,210]$, among several other mechanisms of action [64]. In a meta-analysis including 35 RCTs, probiotics were shown to have beneficial effects with regard to abdominal pain, bloating and flatulence scores in IBS patients [78]. Additionally, authors described superiority of multispecies probiotics to single species probiotics, but found no specific combination of multispecies probiotics predominant to another. As such, clarification with regards to which combinations of species are effective in treating specific IBS subtypes, and optimum treatment dosages and durations are still required [124]. Thus, not enough is known for compounding of probiotics into treatment formulations, or to accurately prescribe probiotic strategies.

An integrated presentation of IBS-associated pathology is also presented visually in Fig. 1. Taken together, the female bias towards exacerbation of IBS symptomology is clear, as well as its prominent links to the actions of microbial-derived metabolites, or as we suggest, the trace aminergic system. We believe that trace amines (which are, at least in part, by-products of microbial metabolism) may provide the molecular link to explain the association between gut microbiome dysbiosis, IBS, inflammation and central nervous system conditions such as depression and anxiety (both high incidence comorbidities in IBS).

\section{The trace aminergic system}

Trace amines (TA) are a class of biogenic amines produced endogenously in humans, but also present in bacterial secretomes and certain foods. Common TA include $\beta$-phenylethylamine (PEA), tryptamine (TRP) and $\rho$-tyramine (TYR), which are derived from their respective amino acid precursors L-phenylalanine, L-tryptophan and L-tyrosine. Synthesis of TA primarily occurs through the enzymatic action of aromatic L-amino acid decarboxylases (AADC) [17]. While endogenous synthesis of TA is often reported to be neuronal, AADC are also present in non-neuronal tissues, including the epithelium of the GI tract [122, 226]. Additional sources of TA include those derived from food and microbes.

Trace amine-associated receptor (TAAR) 1 is the most thoroughly studied of the receptors in humans and has both central (acts as a rheostat of dopaminergic, glutamatergic, and serotonergic neurotransmission) and peripheral (regulates nutrient-induced hormone 


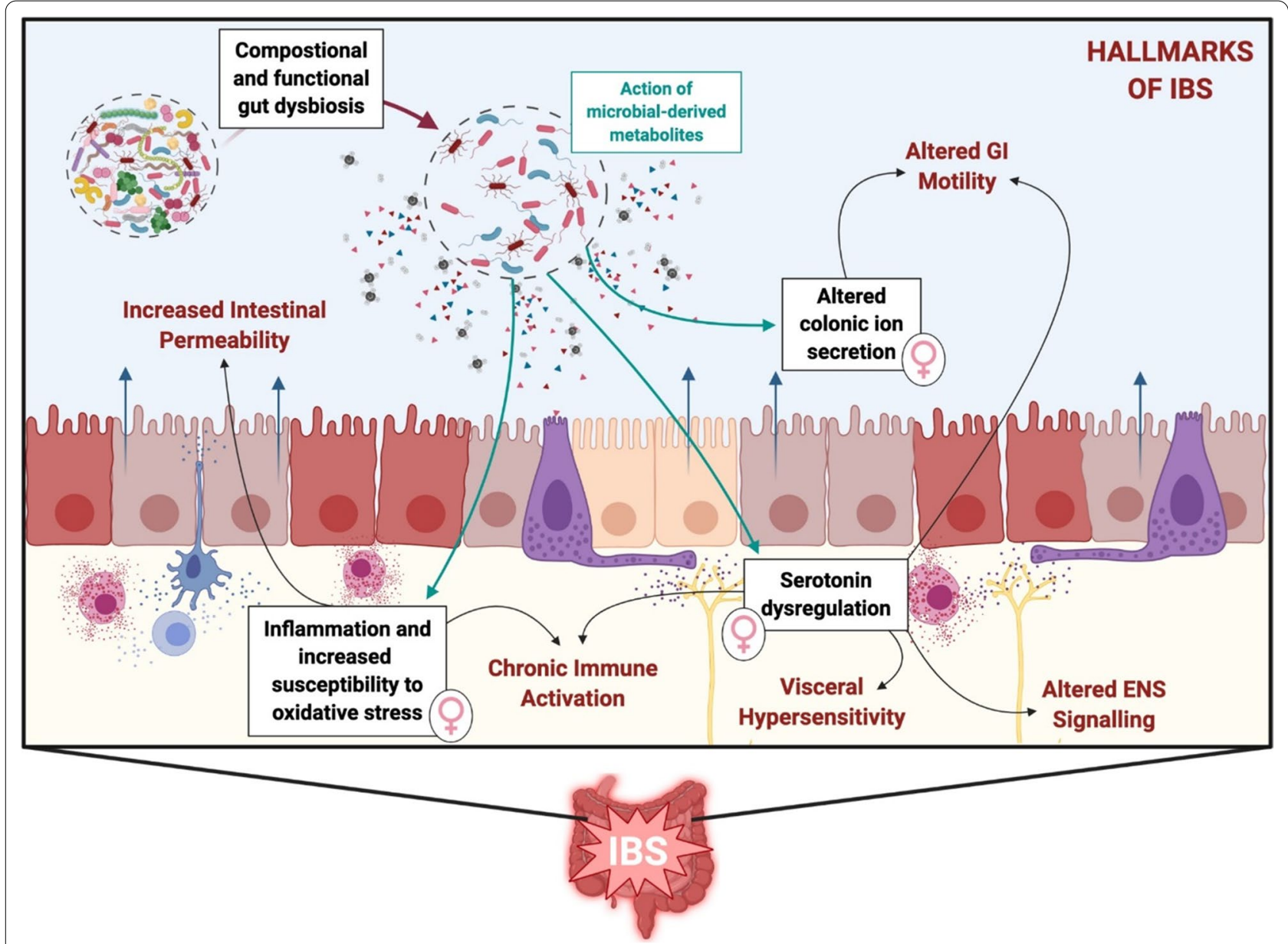

Fig. 1 A simplified visualisation of IBS-associated pathology. G/ gastrointestinal, EC enterochromaffin, 5-HT serotonin

secretion and immune responses) roles [80]. In the next few sections, we review different aspects of the trace aminergic system, as it relates to IBS.

\section{$T A$ "toxicity" risk}

Interestingly, foods containing high levels of TA, such as cheese, wine, sausages and other fermented foods-all commonly linked to exacerbated symptoms in IBS-are foodstuffs largely dependent on bacterial fermentation $[107,153,155]$. Lactic acid bacteria (LAB) are considered the primary biogenic amine producers in fermented foods. Indeed, various Lactobacillus spp. starter cultures have been studied with the aim of mitigating the potential health risks (headaches, heart palpitations, vomiting and diarrhoea) associated with excessive biogenic amines levels [7]. Interestingly, the authors of this study reported that TYR and PEA were produced by $14.4 \%$ and $12.4 \%$ of LAB isolates (fermented sausages) respectively, all belonging to L. curvatus species. As such, the authors recommended that $L$. sakie be used as the predominant
$\mathrm{LAB}$ in preparation of these sausages in the future. In fact, the inability of a strain to synthesize biogenic amines is included in the selective criterion for malolactic starter cultures [220]. It is, however, important to highlight that the biogenic amine producing ability is a strain-specific characteristic, as variability in aminobiogenetic potential between different strains belonging to the same species is evident [13]. Regardless, the link between TA levels and fermentation is clear. Indeed, the expression (transcriptional induction) and/or activation (catalytic modulation) of LAB amino acid decarboxylation systems is reportedly an adaptive response to energy depletion, and is considered a strategy that counteracts acid stress [180], since decarboxylase activity can lead to membrane energization and increased environmental $\mathrm{pH}$. Moreover, the strain dependent (rather than species specific) presence of decarboxylases genes involved in biogenic amine production eludes to horizontal gene transfer between strains as an adaptive mechanism of survival in specific environments (such as the GIT) $[51,131,136]$. Therefore, 
these decarboxylation mechanisms represent an important ecological tool, which can confer a competitive advantage in acid or nutritional stress conditions [75, $178,179,195]$.

Of the potential health risks related to biogenic amines, the most severe symptoms are said to be caused by histamine and TYR [13]. Interestingly, a study investigating the self-reported food intolerance of 197 IBS patients, reported that $84 \%$ of these individuals recounted symptoms related to at least one of the surveyed foodstuffs, of which, 58\% experienced GI symptoms from foods rich in biogenic amines (wine, beer, salami and cheese) [28]. Additionally, histamine-containing food were also considered as causes of IBS-related symptoms. The resultant symptoms are reportedly induced via chemo-stimulation of gut or immune cell receptors [88]. Of note, the authors also reported that females reported more food items causing symptoms than males [28], although no potential explanation was provided. This study, along with several others, emphasises the high perceived food intolerance among IBS patients [57, 152, 211]. Histamine (a weak TAAR1 agonist) is directly involved in inflammation, while TYR intoxication facilitates the "cheese reaction". This reaction, most commonly described in the context of cheese consumption, is the result of a food-drug interaction, where the food can be any TYR rich food and the drug usually a non-selective monoamine oxidase inhibitor (MAOI). Mechanistically, TYR increases sympathetic responses by indirectly acting as a sympathomimetic (displaces stored norepinephrine (NE)), thereby increasing the levels of circulating NE. The use of MAOI exacerbates this action by inhibiting the metabolism of both TYR and NE. As such, symptoms of the "cheese reaction" include dietary-induced migraine, nausea, vomiting, increased cardiac output, respiratory difficulties and elevated blood glucose levels [135]. This has had important implications in patients using MAOI, in which not even low levels of biogenic amines can be metabolised effectively [200]. MOAI have been prescribed to patients with chronic anxiety to improve 5-HT signaling, and intriguingly, 54 to $94 \%$ of treatment-seeking IBS patients will have a co-morbid psychiatric disorder $[67,199]$ of which, anxiety and depression are the most common. The resultant biogenic amine sensitivity that these patients experienced led to the development of new generation MAOI, so-called reversible MAO-A inhibitors [145].

As mentioned, histamine is indeed a weak TAAR1 agonist [250], and various reports suggest between 5 and $>50 \mu \mathrm{M}$ are required for the activation of TAAR1 (similar potency as TRP, NE and synephrine) [29, 127, 237]. Even though patients with IBS reportedly have elevated levels of histamine in mucosal supernatants/biopsies, of up to $50 \mathrm{ng} / \mathrm{mL} \mathrm{mg} \mathrm{[32,91],} \mathrm{it} \mathrm{is} \mathrm{unlikely} \mathrm{that} \mathrm{these} \mathrm{endogenous}$ levels result in TAAR1 activation. However, exogenous or dietary histamine consumption could contribute significantly to the levels of histamine in the gut, contributing to potentially detrimental effects-although most likely independent of TAAR1 activation. For example, certain fish and varieties of cheeses contain up to $2000 \mathrm{mg} / \mathrm{kg}$ of histamine, and the ingestion of $75 \mathrm{mg}$ of histamine is reported to cause symptoms of intoxication in healthy individuals $[188,236]$. A recent study by del Rio et al. [60] also reported that co-treatment (on HT-29's) with TYR and histamine was associated with stronger (or synergistic) cytotoxic effects in vitro than treatment with either TYR or histamine alone, an effect achieved in the absence of TAAR1. These results indicate that histamine increases the cytotoxicity of TYR at concentrations prevalent in some foods (levels generally considered safe for consumption) [60].

While the symptoms of the "cheese reaction" and histamine intoxication are not specific to IBS, other biogenic amines may similarly trigger IBS-specific symptoms by promoting visceral hypersensitivity via the action of bioactive mediators and/or luminal distention [10, 55, 238]. As such, other biogenic amines (PEA, putrescine, cadaverine, agmatine and spermidine) can also cause toxicity, but in cases where multiple biogenic amines are present, they are said to potentiate the effects of histamine and TYR by inhibiting their metabolizing enzymes [176]. Taken together, the toxicity of any biogenic amine will depend on the type of amine, the amount of amine, the individual host sensitivity or allergy, and the consumption of MOA inhibitory drugs (or ethanol), which inhibits or reduces the aminooxidase enzymatic systems responsible for the detoxification of exogenous amines [207].

While these health risks are well-researched with regard to food safety and regulation [201], it is concerning that many LAB are commonly used as probiotics. Indeed, another study has raised concern that some Lactobacillus rhamnosus strains often used in probiotics may produce biogenic amines [129]. Moreover, not only LAB predominant probiotics should be considered, but probiotics with Enterococcus, Streptococcus, and Lactococcus species may also potentially produce biogenic amines [13]. In fact, decarboxylase activity is often expressed independently of cell viability, since these enzymes maintain activity after cell lysis, even in harsh environmental conditions $[82,120,154,196]$. As such, it may be premature to advocate probiotic treatment as a blanket supplementation strategy for therapeutic relief of IBS patients, and at least some individualisation is required to increase efficacy and mitigate risks of adverse outcomes. Beyond the importance of investigating the decarboxylation activity of probiotic or functional cultures before their use, in the context of gastrointestinal disease and symptomology, 
it may also be important to elucidate negative effects (if any), that chronic exposure to low levels of these biogenic amines could cause.

\section{Microbial-derived TA modulate host functioning}

It is proposed that through the production of bioactive metabolites, such as biogenic amines, the gut microbiota may increase an individual's susceptibility to GI inflammation via modification of intestinal epithelial function and mucosal immune activity [46, 235]. For example, several intestinal microbes synthesize various amino acid decarboxylases, which means that they have the capability to sequester amino acids, convert them into TA, and thereby alter the distribution of metabolites, such as calcium, 5 -HT, trimethylamine $\mathrm{N}$-oxide (TMAO) and immune cell mediators in the host, as part of the symbiotic relationship between the gut microbiome and host. However, changes in TA metabolism have already been correlated to both inflammation of the bowel [233] and decreased microbiome complexity (dysbiosis) [205], which suggests that in pathological states, this altered TA metabolism may have functional consequences, that may manifest as or promote disease symptomology. Given the strong links of IBS with depression, and that microbial-derived biogenic amines are similar in structure to monoamine neurotransmitters, TA/TAAR1 should be considered as potential biomarkers and/or therapeutic targets. To motivate this point, this section will discuss (i) the significant presence of TA-producing microbes in the gut, (ii) the optimal conditions of a dysbiotic gut for the generation of microbial-derived TA and, finally (iii) an example of functional modulation by trimethylamine (TMA) and TMAO.

Firstly, in intestinal metagenomes of healthy individuals, tryptophan decarboxylase homologs were found to be present in $9 \%$ to $17 \%$ of individuals, suggesting that microbe-derived TRP may be more prevalent in the gut than previously thought [232]. Indeed, the gut microbiome of IBS patients is often dominated by Firmicutes [105], the phylum from which the majority of the tryptophan decarboxylases derive. In fact, the gut microbiota features a myriad of metabolizing enzymes, such as various decarboxylases, dehalogenases and amine oxidases, which may facilitate the formation of other TAs (e.g. octopamine and synephrine), as well as functionally active TA-metabolites. While no studies have investigated the percentage of TA producing bacteria in IBS populations compared to healthy individuals, these results suggest that the TA-production capacity of the gut microbiome is significant, and has been largely overlooked or underestimated.

Secondly, according to two independent in vitro studies on known microbial producers of TA (Lactobacillus brevis CECT 4669, Enterococcus faecium BIFI-58 and E. faecium EF37), various physiochemical factors influence microbial synthesis of TA [81, 138]. These factors include incubation temperature and time, environmental $\mathrm{pH}$, pyridoxal-5-phosphate supplementation, sodium chloride concentration and most importantly, amino acid substrate availability, most of which are optimal within the human GIT. Of note, some of these factors may be altered in pathological states, towards promoting microbial TA production. For example, luminal $\mathrm{pH}$ is reportedly altered in individuals with dysbiosis, and this may contribute to mucosal inflammation and enterocyte dysfunction [24]. With regard to IBS, Ringel-Kulka et al. [190] reported that colonic intraluminal $\mathrm{pH}$ levels were significantly lower in IBS patients (all disease subtypes) when compared to controls. Similar findings have also been reported in patients with IBD [164], with one study reporting low colonic luminal $\mathrm{pH}$ values ( $\mathrm{pH} 5.3$ patients vs $\mathrm{pH} 6.8$ controls), which were associated with active disease states [206]. Interestingly, a pH range of 4 to 5.5 is reported to increase amino acid decarboxylase activities and thus enhance TA production [81, 138]. This microbial response is a well-documented adaption to $\mathrm{pH} / \mathrm{acid}$ stress (as already briefly discussed in "TA "toxicity" risk" section), and suggests that more efficient TA production may occur in individuals with dysbiosis.

Finally, TMA is a selective agonist of TAAR5 [126, 227, 245], and there is no known mammalian pathway for its synthesis. As such, the production of TMA seems to be exclusive to the metabolism of choline, betaine, and carnitine by microbes [52, 108, 248], with the administration of antibiotics to mice, reducing the levels of urinary TMA $[79,240]$. Interestingly, raised levels of TMA have been reported to result from dysbiosis at various mucosal sites, such as intestines, in both mice and human models [74, 246]. While increased levels of TMAO are generally associated with extra-intestinal diseases (CVD), TMAO may cause intestinal inflammation and oxidative stress [40]. Considering that TAAR5 expression has been reported for several leukocyte populations [8], particularly B lymphocytes, it is clear that increased levels of either TMA or TMAO could be involved in initiating or perpetuating intestinal inflammation, as is common in IBS. Moreover, altered levels of TMA/TMAO can reportedly alter the growth and secretion of metabolites of several intestinal bacteria [102]. As such, TMA/TMAO not only affects host functioning, but can alter the luminal environment too, perpetuating dysbiosis.

\section{Mechanism of action of TA in the gut}

Perhaps due to a relative lack of cross-disciplinary communication in this context, despite the knowledge of their existence, or perhaps as a result of the bias in favour 
of compositional, rather than functional assessment of the gut microbiome, data on the specific actions of TA in the human gut are still relatively limited. However, some insights into the function of TA in the context of IBS may be derived by considering their extra-intestinal effects.

\section{Direct cellular effects of TA}

Direct cytotoxic effects of PEA, TRP and TYR on MonoMac-6 and HEK293 cell lines was investigated (MTT assay) [133]. Data showed that $62.5 \mu \mathrm{g} / \mathrm{mL}$ of each TA independently reduced MonoMac- 6 viability by $20 \%$, and $125 \mu \mathrm{g} / \mathrm{mL}$ of TRP reduced MonoMac- 6 viability by $80 \%$. While the HEK293 cells were more resistant to the cytotoxic effects of the TA, $500 \mu \mathrm{g} / \mathrm{mL}$ of TRP also reduced viability by more than $80 \%$. From this study, the most cytotoxic TA seems to be TRP, while TYR had the least cytotoxic effects. However, the lack of an in vivo context limits the interpretations which can be made by these data. Moreover, the lack of reported absolute concentrations of endogenous TAs in the gut/intestinal mucosa of humans makes it difficult to draw firm conclusions on the physiological relevance of these findings and the specific doses. To "bridge" this gap in literature, we propose the consideration of firstly, the contribution of exogenous TA consumption (in food) to levels in the gut. For example, it has been previously reported that dietary concentrations of PEA and TYR indeed stimulate the gut, altering intestinal blood flow in an ex vivo model [31]. Secondly, we considered that the contribution of TAs derived from major TA-producing microbes in vitro, suggests that the TA range selected for the generation of the WST-1 data is feasible. For example, Staphylococcus pseudintermedius ED99 cultured in media containing $2 \mathrm{mg} / \mathrm{mL}$ of L-tryptophan, L-phenylalanine and L-tyrosine produces $231 \pm 10 \mu \mathrm{g} / \mathrm{mL}$ TRP, $557 \pm 8 \mu \mathrm{g} / \mathrm{mL}$ of PEA and $360 \pm 9 \mu \mathrm{g} / \mathrm{mL}$ TYR in vitro [133]. These data suggest that in the gut, in the presence of potentially numerous TA-producing microbes, significant concentrations of TAs may be present. Thus, while the endogenous levels of TAs are not known, the exogenous (and potentially endogenous) contribution may be significant enough to suggest physiological relevance.

Moreover, the presence or production of TA is reported to enhance the ability of Staphylococcus and Enterococcus spp. to adhere to intestinal epithelium, promoting consequential internalization and enterocyte cytokine secretion $[75,133]$, potentiating colonization as a potential adaptive advantage for these species. Indeed, TA bound to the $\alpha 2$-adrenergic receptor induced cytoskeletal reorganisation, which facilitated host cell colonization to boost adherence of both TA-producing and non-TA-producing bacteria [133]. Interestingly, the addition of $10 \mathrm{mM}$ tyrosine (which resulted in formation of \pm 140 nmol TYR) significantly improved bacterial adherence to colon epithelium by threefold, while direct supplementation with $140 \mu \mathrm{M}$ of TYR did not affect adherence [75]. The authors speculated that the activation of the TYR biosynthetic pathway, rather than the production of TYR, could be involved in the enhancement of microbial adhesion. Nevertheless, this data illustrates the complex mechanisms at play to facilitate TA effects.

Taken together, these results suggest that dose specificity is an important consideration. What is not known, is the range in which microbes potentially benefit from TA (producing or produced), while conferring host cytotoxicity, and what implications this could have for IBS.

In terms of enteroendocrine function, PEA was reported to stimulate gastrin secretion from stomach G cells in a rat model [61]-which in the IBS context is linked to ulceration and dyspepsia [69]. This again points to a direct detrimental effect of TA in the IBS context.

With regard to colonic ion secretion, TRP in particular was reported to promote colonic ion secretion [232], however the nature of this ion secretion and potential preference to a specific ion(s) were not reported and thus, require further investigation before interpretation of the significance of this finding is possible. Nevertheless, this data potentially suggests that TRP-mediated signalling might affect GI transit. Furthermore, from the known effects already outlined for E2, we can postulate that in general E2 and TAs, such as TRP, have opposing effects on colonic ion secretion and GI motility. This could explain an exacerbation of symptomology during menses, when ion secretion and thus GI motility shifts from one side of the spectrum to the other in female patients, an effect that would be heightened in the presence of a high TA (or at least TRP) load. The potential of manipulating TRP levels to achieve optimal GI transit in IBS, warrants TA profiling in IBS.

\section{Modulation of oxidative stress and inflammation}

Intracellular accumulation of $\mathrm{Ca}^{2+}$ is commonly associated with oxidative stress, damage and inflammation in various chronic conditions. Of relevance in this context, binding of TA to human TAAR1 results in the influx of $\mathrm{Ca}^{2+}$ as a result of activated TAAR1 coupling to $\mathrm{G \alpha}_{\mathrm{s}}$ and $\mathrm{G}_{\mathrm{q}}$ proteins [158]. Upon stimulation of these G-proteins, intracellular messengers such as cAMP and $\mathrm{IP}_{3}$ accumulate and activate downstream proteins such as PKB and PKC, which mobilize intracellular $\mathrm{Ca}^{2+}$ stores, as well as promote extracellular $\mathrm{Ca}^{2+}$ influx [29, 30, 33, 127]. Excessive $\mathrm{Ca}^{2+}$ influx may lead to endoplasmic reticulum stress and mitochondrial dysfunction, rendering a cell with an unfavourable redox profile, and thus several regulatory mechanisms intricately control intracellular $\mathrm{Ca}^{2+}$ levels. 
However, in overabundance of TA, regulatory mechanisms may be overwhelmed. In line with this, histamine-a known mediator of inflammation and known to be increased in IBS - has also been reported to increase the intracellular $\mathrm{Ca}^{2+}$ response in an EC cell line (P-STS) [181]. Apart from the resultant direct oxidative stress, histamine and TA may also exacerbate aberrant 5-HT signalling linked to IBS symptomology (altered GI motility, visceral hypersensitivity and immune activation). Interestingly, TA may also indirectly cause increased susceptibility to oxidative stress through their modulation of serotonin, as $5-\mathrm{HT}_{2 \mathrm{~A}}$ receptor activity was found to increase intracellular calcium via the mitogen-activated protein kinase pathway [229]. This may cause an intracellular $\mathrm{Ca}^{2+}$ burden within the surrounding intestinal tissue, resulting in symptoms such as abdominal pain. As such, it may be important to consider targeting TA availability or modulation of TAAR1 expression in an effort to curb $\mathrm{Ca}^{2+}$-associated visceral hypersensitivity in IBS patients with severe abdominal pain.

Another common trace amine, 3-iodothyronamine $\left(\mathrm{T}_{1} \mathrm{AM}\right)$, may also contribute to changes in $\mathrm{Ca}^{2+}$ homeostasis and alter the pro- and antioxidant balance in the intestine and surrounding tissue by interacting with various receptors (such as $\alpha 2$-adrenergic receptor) [101,249]. For example, $\mathrm{T}_{1} \mathrm{AM}$ reportedly increased the amount of hydrogen peroxide released by rat liver mitochondria [223]. Interestingly, Chiellini et al. [42] reported that exogenous $\mathrm{T}_{1} \mathrm{AM}$ (and its metabolites) primarily undergo biliary and urinary excretion, and subsequent reports have suggested the presence of significant endogenous levels of $\mathrm{T}_{1} \mathrm{AM}$ in stomach and intestine, at least in mice [100], suggesting that the pro-oxidative effects of $\mathrm{T}_{1} \mathrm{AM}$ may not be limited to the liver. While the precise biosynthesis of $\mathrm{T}_{1} \mathrm{AM}$ in humans remains to be confirmed, Hoefig et al. [100] has demonstrated that the intestine expresses the enzymatic machinery (intestinal deiodinases and ornithine decarboxylase) required for T1AM biosynthesis from thyroxine, while other authors highlight the potential of the gut microbiota to generate T1AM $[89,203]$. In terms of relevance to IBS, interactions of T1AM with histaminergic circuitries has been proposed [249], warranting investigation in the context of both inflammation and oxidative stress related symptomology.

In terms of inflammation a relatively recent metabolomics study indicated elevated faecal PEA levels in patients with Crohn disease [103], suggesting a proinflammatory effect for trace aminergic signalling. Similarly, abundance of Faecalibacterium prausnitzii-a species that has a reported role in mitigating inflammation in the colon [128, 149]-also correlated inversely with PEA levels in IBD patients [205]. Since significant consumption of phenylalanine is associated with growth of $F$. prausnitzii [95], its absence in dysbiotic conditions may increase the availability of phenylalanine to TA-producing microbes, resulting in elevated PEA levels. This potential mechanism should be evaluated more comprehensively in IBS-specific models.

Furthermore, PEA and TYR are chemotactic for polymorphonuclear cells (PMN) [8], major role players in inflammation and in particular, secondary damage to host tissue during inflammation. Considering that low levels of TA are normally present in the GIT-the interface between mucosal immunity and microbes-it is possible that in dysbiosis, the ensuing immune activation and altered microbial behaviour may promote or exacerbate intestinal inflammation. Within the context of IBS, and specifically female-predominance, it is necessary for future experiments to elucidate the contribution of TA to chronic intestinal inflammation, and whether or not female reproductive hormones affect this in any way.

\section{The role of TAARs}

Most TAAR-related research to date was performed in microbiology contexts. Although some neurophysiology investigations have reported on TAAR, this niche is largely unexplored. Generally, the available literature seem to suggest that TA and TAAR are not exclusively "paired", with TA able to act as ligand for several other receptors. Furthermore, TAARs-in particular TAAR1-seems to be a rate-limiting factor in TA-associated effects, as its presence have been linked to opposite effects than described for TA.

For example, in contrast to the over secretion of gastrin linked to TA, TAAR1 activation by a selective small molecule agonist was associated with elevated plasma levels of peptide tyrosine tyrosine (PYY) and glucagonlike peptide-1 (GLP-1) [186], which may be protective, as decreased levels of secreted PYY and GLP-1 from L-cells are implicated in IBS pathogenesis and symptomology [70, 167]. Similarly, in terms of modulation of leukocyte responses specifically, TAAR1 is differentially expressed in several leukocyte populations, such as PMN, B and T lymphocytes, monocytes, and natural killer cells $[8,56$, $160,214]$, thus TAAR1 activation may regulate leukocyte differentiation and activation. Indeed, expression of both TAAR 1 mRNA and protein components are upregulated in primary human lymphocytes after activation with PMA and PHA [160, 228]. However, one would expect in the context of IBS, that chronic (rather than acute) activation may downregulate TAAR expression overtime. As such, the importance of conducting in/ex vivo testing should be emphasized, and certainly warrants future investigations. Furthermore, $\mathrm{T}$ helper lymphocyte differentiation toward Th2 phenotype may be regulated 
by the activation of leukocyte TAAR1 and TAAR2 [8]. However, in the same study, TAAR1 and TAAR2 activation were also reported to mediate IL-4 secretion from $\mathrm{T}$ lymphocytes and immunoglobulin $\mathrm{E}$ (IgE) secretion from $\mathrm{B}$ lymphocytes [8]. Of relevance to the allergy-like symptoms prevalent in IBS, both IL-4 and IgE mediate allergic inflammatory responses $[173,216]$, inducing mast cells to release histamine upon IgE binding, and are implicated as central role players in IBS [12, 125]. This seemingly dichotomous role for TAAR in the activation of immune cells remain to be further elucidated.

In terms of its effect on serotonergic signalling, highest predominance of TAAR 1 is described in neuronal aminergic pathways [18]. Of specific relevance, in a rodent knockout model, the absence of TAAR1 was associated with increased aminergic (dopaminergic and serotonergic) signalling [177], again suggesting a dampening effect for TAAR1. In terms of applicability to this review, IBSassociated 5-HT dysregulation-which is implicated in altered GI motility $[132,221]$ and visceral hypersensitivity [143]-is already therapeutically targeted by $5-\mathrm{HT}_{3} \mathrm{R}$ antagonists [85, 141]. Assuming that a higher TA load results in reduced TAAR1 expression (specifically in EC cells) in chronic conditions, a more accurately targeted approach might include modulation of trace aminergic signalling, thereby eliminating the cause of $5-\mathrm{HT}$ dysregulation.

It is important to note, however, that TAAR signalling is additionally complicated by three factors. Firstly, genetic variations in the form of TAAR polymorphisms, as well as their clinical relevance, cannot be excluded [46], since function-altering polymorphisms of TAAR1 [209] and TAAR2 [27] have already been reported. Secondly, TAAR expression is often recorded in acute, in vitro models. According to basic ligand/receptor relations, receptor expression is generally downregulated when ligands are overexpressed chronically, however, this notion is complicated by the very location and nature of TAARs. It is generally accepted that TAAR 1 is primarily located intracellularly [177]. How this unique behaviour translates to altered receptor expression is still unknown. Lastly, TAAR reportedly undergoes heterodimerization, which may result in biased signalling outputs [19]. Indeed, it has been reported that this heterodimerization modulates the signalling capacities of GPCRs, thereby altering their sensitivity for ligands [63, 202]. Putative candidates include adrenergic, serotoninergic, dopaminergic and glutaminergic receptors, and as such, signal modulation by receptor pairs is largely underestimated, especially considering the vast expression of GPCRs in any one cell [189]. Interestingly, GPCR distribution and expression is dependent on several factors, including gender and disease condition. To add to the complexity, intermediate receptor pairings have also been suggested [212], further complicating pharmacological and drug discovery studies. As such, Berry et al. [18] suggested targeting GPCR dimers, which should mitigate undesired side effects and increase ligand selectivity.

These data suggest that TAAR1 may have a modulatory (down-regulatory) role in trace aminergic signalling, but that this effect may be dependent on nature of receptors with which heterodimers are formed upon ligand binding. Given the clear role for TA in IBS aetiology and symptomology, elucidation of the potential of TAAR as therapeutic target is high priority.

The importance of the trace aminergic system as a multipronged role player, which effects many sites, is visually represented in Fig. 2. This includes a summary of the known functions of TA in the GIT, and the plausible links to IBS symptomology.

\section{Is trace aminergic signalling gender dependent?}

Turning attention back now to the female predominance in IBS, it is important to consider whether trace aminergic signalling also shows gender-dependence, as this may impact on not only drug discovery, but also patient management.

Indeed, with the emergence of the concept "microgenderome", researchers have shown that the microbiome is both shaped by reproductive hormones and that the microbes in turn are able to regulate levels of these hormones [76]. An example of this is prevalent when one considers the more specific "estrobolome" [119, 183], which collectively encompasses intestinal microbes (or rather their gene repertoire) capable of producing estrogen metabolizing enzymes (such as $\beta$-glucuronidase). In healthy individuals the actions of the estrobolome increases intestinal reabsorption of estrogens, while in dysbiotic conditions this is reduced [9]. Similarly, the microgenderome can also modulate 5 - $\mathrm{HT}$ signaling (as discussed earlier) and interestingly again do so via estrogens. As such, the effect that altered trace aminergic signalling could have on 5-HT release and action, could be predetermined by lifelong exposure to and priming by E2.

Furthermore, TAAR signalling is differentially activated by distinct TA profiles in different genders. Indeed, in a study by Liberles and Buck [126] murine TAAR5 was reported to respond strongly to extremely diluted urine from male mice, but not female mice or prepubescent males. Notably, three ligands identified for murine TAARs (mTAARs) are natural components of mouse urine: PEA, isoamylamine and TMA, which act as ligands for mTAAR4, mTAAR3 and mTAAR5 respectively, of which isoamylamine and TMA are enriched in male vs female mouse urine [83, 161]. Furthermore, isoamylamine in male urine is reported to act as a pheromone, 


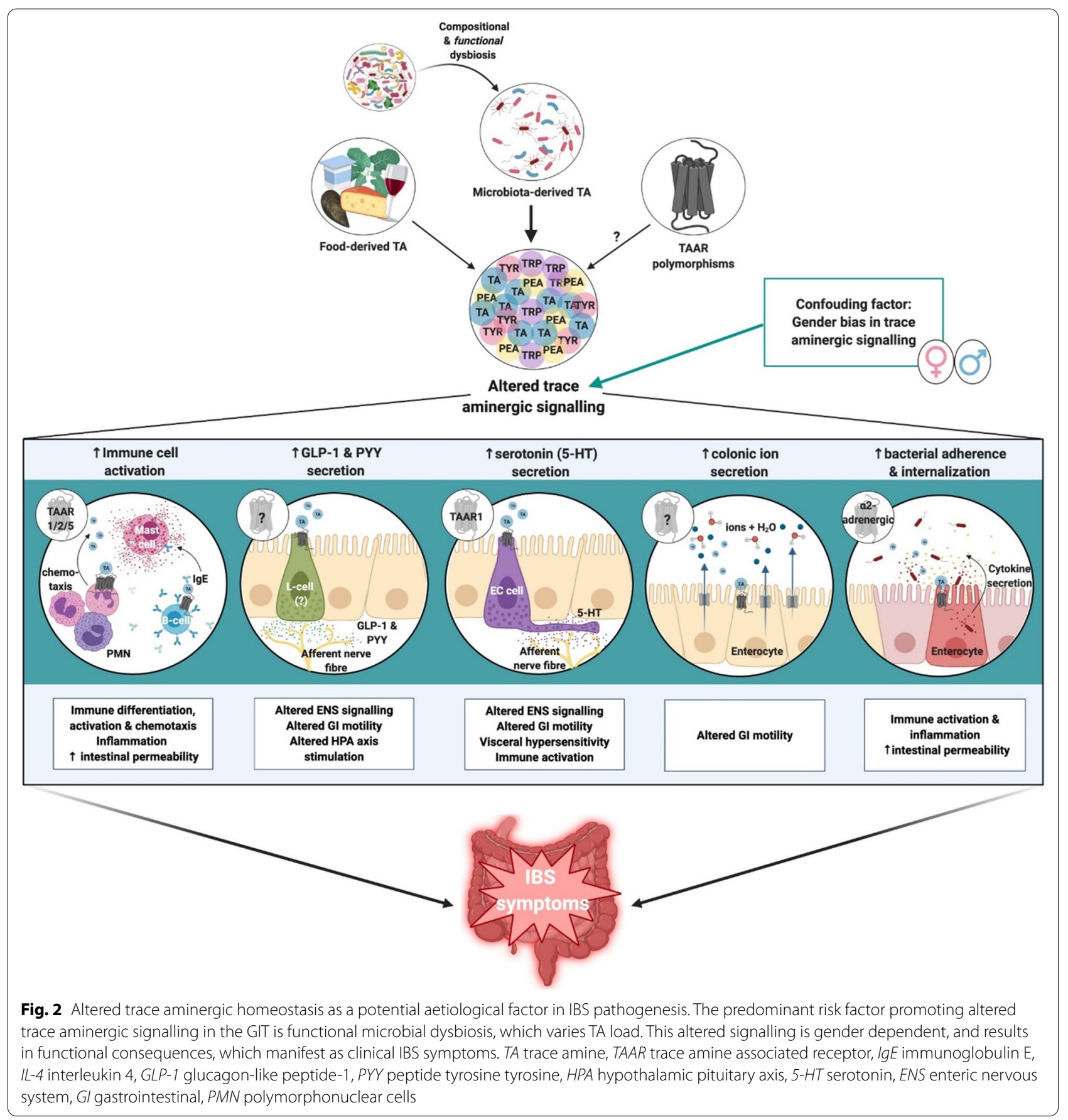

fast-tracking the onset of puberty in female mice [161]. Thus, by utilizing mTAAR5, mice could theoretically determine the gender and sexual status of other mice, which suggest that at least some mTAARs detect social cues $[94,163]$ that may stimulate certain behaviours or physiological responses. While this study has not been replicated in humans, we are of the opinion that altered trace aminergic signalling (as reported in modern chronic diseases) may be the result of altered gender dynamics. In modern society, with the rise of female emancipation and modern hygiene practices, both females and males may have inadvertently altered their 'social cues'. This of course remains to be confirmed, as this may have farreaching implications for disease preventative strategies in IBS-high risk populations. Nevertheless, the little available data suggest that amount and distribution of at 
least some TA within a host are gender (or even sexual status) specific, which may have implications for diseases in which onset parallels the onset of puberty, such as IBS.

Another link between gender and altered TA homeostasis is chronic psychological stress. According to several studies, elevated PEA levels in urine correlated with increased stress and stress response, in both humans and rodents [65, 92, 174, 213]. Typically, it was thought that women are more vulnerable to life stress [208, 241], and are more prone to depression, anxiety and somatization than men [2, 25, 49]. Women also seem to present with exaggerated IBS symptoms when stressed [98]. In addition, gender-related differences in the prevalence of depression becomes apparent after menarche and continued until peri-menopause [93], which parallels IBS symptom peak onset. These studies, along with several more recent studies, report evidence for sexual dimorphism in stress response in the context of IBS [110, $111,225]$. However, the link between chronic stress and increased urinary PEA levels is less clear, although limited research to date does again point to an estrogen link in this context. Interestingly, in a study investigating the relationship of urinary PEA levels and personality traits (MMPI) in healthy individuals, reported that males had lower PEA levels [151], a finding that had previously also been reported [182]. Although concrete mechanisms and IBS specific data is lacking, current data supports an interpretation in favour of a gender dependence in trace aminergic signalling. As such, fluctuations of especially female reproductive hormones may alter trace aminergic signalling. Given the comprehensive body of literature that already exist on female reproductive hormone replacement therapy, it may be possible to expand on the manipulation of hormone levels for therapeutic effect in IBS. This option warrants further research in this context.

\section{Where to from here?}

From the literature reviewed here, both female reproductive hormones (especially E2) and TA potentially modulate EC cell functioning. While no studies have directly explored the role of an altered trace aminergic system in patients with IBS, it is eluded to. The fact that TAARs are present in almost all leukocyte populations, and the supply of significant amounts of their ligands (TA) originate from food and gut microbiota, suggests that the trace aminergic system is conveniently positioned at the interface of diet/nutrition, gut microbiome, and mucosal immunity, all of which are implicated as aetiological factors in IBS pathogenesis. In terms of proposed mechanisms, dyshomeostasis of the trace aminergic system may result in altered colonic ion secretion, hyperreactivity of the immune system and fluctuations of 5-HT levels causing aberrant 5-HT signalling. While disruption of trace aminergic homeostasis may occur due to TAAR polymorphisms or increased TA supply due to changes in diet, functional microbial dysbiosis seems to be the predominant risk factor. Aberrant trace aminergic functioning can result in altered leukocyte differentiation, activation and chemotaxis, all while microbes more efficiently adhere to and infiltrate intestinal epithelium. The ensuing pro-inflammatory state of the gut could manifest in the symptomology clinically prevalent in IBS. As such, we suggest that microbial-derived TA (and the functional consequences perpetuated by the trace aminergic system) should be considered aetiological factors in the pathogenesis of IBS. Furthermore, since an altered trace aminergic system results in fluctuations of intestinal 5 -HT, which is already targeted for modulation by current medications for IBS, then it is feasible to suggest that TAARs be considered targets for future therapeutic action, with the specific focus of reducing oxidative stress and inflammation.

\section{Conclusions}

In conclusion, the microgenderome concept may explain, at least in part, the gender bias observed in many chronic inflammatory conditions. The notion of host-intrinsic factors, which are reinforced and manipulated by commensal bacteria, could underpin the relationship between an altered trace aminergic homeostasis and female predominance in IBS. In order to elucidate the nature of relationship between the trace aminergic system and reproductive hormones, specifically E2, and their influence on IBS, areas of overlap, such as modulation of serotonin and ion secretion and susceptibility to oxidative stress and inflammation requires further investigation.

\section{Abbreviations \\ IBS: Irritable bowel syndrome; IBD: Inflammatory bowel disease; GI: Gas- trointestinal; GIT: Gastrointestinal tract; ERs: Estrogen receptors; MDA: Malondialdehyde; 5-HT: Serotonin/5-hydroxytryptamine; EC: Enterochromaf- fin; E2: 17ß-Estradiol; SERT: Serotonin reuptake transporter; Prog: Proges- terone; SIBO: Small intestinal bacterial overgrowth; TA: Trace amines; PEA $\beta$-Phenylethylamine; TRP: Tryptamine; TYR: $\rho$-Tyramine; AADC: Aromatic L-amino acid decarboxylases; TAAR: Trace amine associated receptors; LAB: Lactic acid bacteria; MAOI: Monoamine oxidase inhibitor; NE: Norepinephrine; TMAO: Trimethylamine N-oxide; TMA: Trimethylamine; T, AM: 3-lodothyron- amine; PMN: Polymorphonuclear cells; GLP-1: Glucagon-like peptide-1; PYY: Peptide tyrosine tyrosine; IgE: Immunoglobulin E.}

Acknowledgements

All figures were created with BioRender.com

\section{Authors' contributions}

The authors jointly conceptualised the manuscript. LP prepared the first draft. CS edited the manuscript. Both authors read and approved the final manuscript

\section{Funding}

Not applicable. 


\section{Availability of data and materials}

Not applicable.

\section{Ethics approval and consent to participate}

Not applicable.

\section{Consent for publication}

Not applicable.

\section{Competing interests}

The authors declare that they have no conflict of interest.

Received: 30 June 2020 Accepted: 15 September 2020

Published online: 28 September 2020

\section{References}

1. Akira S, Takeda K. Toll-like receptor signalling. Nat Rev Immunol. 2004:4:499-511.

2. Altemus M. Sex differences in depression and anxiety disorders: potential biological determinants. Horm Behav. 2006;50(4):534-8.

3. Altemus M, Sarvaiya N, Neill EC. Sex differences in anxiety and depression clinical perspectives. Front Neuroendocrinol. 2014;35(3):320-30.

4. Alzamora R, O'Mahony F, Harvey BJ. Estrogen inhibits chloride secretion caused by cholera and Escherichia coli enterotoxins in female rat distal colon. Steroids. 2011;76(9):867-76

5. Andrews CN, Sidani S, Marshall JK. Clinical management of the microbiome in irritable bowel syndrome. J Can Assoc Gastroenterol. 2020. https ://doi.org/10.1093/jcag/gwz037.

6. Atkinson W, Lockhart S, Whorwell PJ, Keevil B, Houghton LA. Altered 5-hydroxytryptamine signaling in patients with constipation- and diarrhea-predominant irritable bowel syndrome. Gastroenterology. 2006;130(1):34-433.

7. Aymerich T, Martin B, Garriga M, Vidal-Carou MC, Bover-Cid S, Hugas M. Safety properties and molecular strain typing of lactic acid bacteria from slightly fermented sausages. J Appl Microbiol. 2006;100(1):40-9.

8. Babusyte A, Kotthoff M, Fiedler J, Krautwurst D. Biogenic amines activate blood leukocytes via trace amine-associated receptors TAAR1 and TAAR2. J Leukoc Biol. 2013;93:387-94.

9. Baker JM, Al-Nakkash L, Herbst-Kralovetz MM. Estrogen-gut microbiome axis: Physiological and clinical implications. Maturitas. 2017;103:45-53.

10. Balemans D, Mondelaers SU, Cibert-Goton V, Stakenborg N, AguileraLizarraga J, Dooley J, Liston A, Bulmer DC, Vanden BP, Boeckxstaens GE, Wouters MM. Evidence for long-term sensitization of the bowel in patients with post-infectious-IBS. Sci Rep. 2017;7:13606.

11. Barbara G, Feinle-Bisset C, Ghoshal UC, Quigley EM, Santos J, Vanner S, Vergnolle N, Zoetendal EG. The intestinal microenvironment and functional gastrointestinal disorders. Gastroenterology. 2016;150:1305-18.

12. Barbara G, Stanghellini V, De Giorgio R, Corinaldesi R. Functional gastrointestinal disorders and mast cells: implications for therapy. Neurogastroenterol Motil. 2006;18(1):6-17.

13. Barbieri F, Montanari C, Gardini F, Tabanelli G. Biogenic amine production by lactic acid bacteria: a review. Foods. 2019:8(1):17.

14. Bearcroft CP, Perrett D, Farthing M. Postprandial plasma 5-hydroxytryptamine in diarrhoea predominant irritable bowel syndrome: a pilot study. Gut. 1998;42:42-6

15. Bellono NW, Bayrer JR, Leitch DB, Castro J, Zhang C, O'Donnell TA, Brierley SM, Ingraham HA, Julius D. Enterochromaffin cells are gut chemosensors that couple to sensory neural pathways. Cell. 2017;170(1):185198.e116.

16. Bennet SM, Ohman L, Simren M. Gut microbiota as potential orchestrators of irritable bowel syndrome. Gut Liver. 2015;9(3):318-31.

17. Berry MD. Mammalian central nervous system trace amines. Pharmacologic amphetamines, physiologic neuromodulators. J Neurochem. 2004;90(2):257-71.

18. Berry MD. Trace amines and their receptors in the control of cellular homeostasis. In: Farooqui T, Farooqui A, editors. Trace amines and neurological disorders: potential mechanisms and risk factors. Amsterdam: Elsevier Inc.; 2016. p. 107-123.
19. Berry MD, Gainetdinov RR, Hoener MC, Shahid M. Pharmacology of human trace amine-associated receptors: Therapeutic opportunities and challenges. Pharmacol Ther. 2017;180:161-80.

20. Bethea CL, Gundlah C, Mirkes SJ. Ovarian steroid action in the serotonin neural system of macaques. Novartis Found Symp. 2000;230:112-33.

21. Bethea CL, Mirkes SJ, Shively CA, Adams MR. Steroid regulation of tryptophan hydroxylase protein in the dorsal raphe of macaques. Biol Psychiatry. 2000;47:562-76.

22. Betts JA, Moradi Marjaneh M, Al-Ejeh F, Lim YC, Shi W, Sivakumaran H, Tropee R, Patch AM, Clark MB, Bartonicek N, Wiegmans AP, Hillman KM, Kaufmann S, Bain AL, Gloss BS, Crawford J, Kazakoff S, Wani S, Wen SW, Day B, Moller A, Cloonan N, Pearson J, Brown MA, Mercer TR, Waddell N, Khanna KK, Dray E, Dinger ME, Edwards SL, French JD. Long noncoding RNAs CUPID1 and CUPID2 mediate breast cancer risk at 11 q13 by modulating the response to DNA damage. Am J Hum Genet. 2017:101(2):255-66.

23. Bharadwaj S, Kulkarni G, Shen B. Menstrual cycle, sex hormones in female inflammatory bowel disease patients with and without surgery. J Dig Dis. 2015;16(5):245-55

24. Blachier F, Beaumont M, Andriamihaja M, Davila AM, Lan A, Grauso M, Armand L, Benamouzig R, Tome D. Changes in the luminal environment of the colonic epithelial cells and physiopathological consequences. Am J Pathol. 2017;187(3):476-86.

25. Blanchard EB, Keefer L, Galovski TE, Taylor AE, Turner SM. Gender differences in psychological distress among patients with irritable bowel syndrome. J Psychosom Res. 2001;50:271-5.

26. Blum I, Vered Y, Lifshitz A, Harel D, Blum M, Nordenberg Y, Harsat A Sulkes J, Gabbay U, Graff E. The effect of estrogen replacement therapy on plasma serotonin and catecholamines of postmenopausal women. Isr J Med Sci. 1996;32(12):1158-62.

27. Bly M. Examination of the trace amine-associated receptor 2 (TAAR2). Schizophr Res. 2005;80(2-3):367-8.

28. Bohn L, Storsrud S, Tornblom H, Bengtsson U, Simren M. Self-reported food-related gastrointestinal symptoms in IBS are common and associated with more severe symptoms and reduced quality of life. Am J Gastroenterol. 2013;108(5):634-41.

29. Borowsky B, Adham N, Jones KA, Raddatz R, Artymyshyn R, Ogozalek KL, Durkin MM, Lakhlani PP, Bonini JA, Pathirana S, Boyle N, Pu X, Kouranova E, Lichtblau H, Ochoa FY, Branchek TA, Gerald C. Trace amines: identification of a family of mammalian G protein-coupled receptors. Proc Natl Acad Sci USA. 2001;98(16):8966-71.

30. Bradaia A, Trube G, Stalder H, Norcross RD, Ozmen L, Wettstein JG Pinard A, Buchy D, Gassmann M, Hoener MC, Bettler B. The selective antagonist EPPTB reveals TAAR1-mediated regulatory mechanisms in dopaminergic neurons of the mesolimbic system. Proc Natl Acad Sci USA. 2009;106(47):20081-6.

31. Broadley KJ, Akhtar Anwar M, Herbert AA, Fehler M, Jones EM, Davies WE, Kidd EJ, Ford WR. Effects of dietary amines on the gut and its vasculature. Br J Nutr. 2009;101(11):1645-52.

32. Buhner S, Li Q, Vignali S, Barbara G, De Giorgio R, Stanghellini V, Cremon C, Zeller F, Langer R, Daniel H, Michel K, Schemann M. Activation of human enteric neurons by supernatants of colonic biopsy specimens from patients with irritable bowel syndrome. Gastroenterology. 2009;137:1425-34.

33. Bunzow JR, Sonders MS, Arttamangkul S, Harrison LM, Zhang G, Quigley DI, Darland T, Suchland KL, Pasumamula S, Kennedy JL, Olson SB, Magenis E, Amara SG, Grandy DK. Amphetamine, 3,4-methylenedioxymethamphetamine, lysergic acid diethylamide, and metabolites of the catecholamine neurotransmitters are agonists of a rat trace amine receptor. Mol Pharmacol. 2001;60(6):1181-8.

34. Camilleri M. Intestinal secretory mechanisms in irritable bowel syndrome-diarrhea. Clin Gastroenterol Hepatol. 2015;13(6):1051-7 (quiz e1061-1052)

35. Camilleri M. Serotonin in the gastrointestinal tract. Curr Opin Endocrinol Diabetes Obes. 2009;16(1):53-9.

36. Carroll IM, Chang YH, Park J, Sartor RB, Ringel Y. Luminal and mucosalassociated intestinal microbiota in patients with diarrhea-predominant irritable bowel syndrome. Gut Pathog. 2010;2(1):19.

37. Casen C, Vebo HC, Sekelja M, Hegge FT, Karlsson MK, Ciemniejewska E, Dzankovic S, Frøyland C, Nestestog R, Engstrand L, Munkholm P, Nielsen OH, Rogler G, Simrén M, Öhman L, Vatn MH, Rudi K. Deviations in 
human gut microbiota: a novel diagnostic test for determining dysbiosis in patients with IBS or IBD. Aliment Pharmacol Ther. 2015;42:71-83.

38. Casimir GJ, Lefevre N, Corazza F, Duchateau J, Chamekh M. The acid-base balance and gender in inflammation: a mini-review. Front Immunol. 2018:9:475.

39. Chadwick VS, Chen W, Shu D, Paulus B, Bethwaite P, Tie A, Wilson I. Activation of the mucosal immune system in irritable bowel syndrome. Gastroenterology. 2002;122:1778-833.

40. Chan CWH, Law BMH, Waye MMY, Chan JYW, So WKW, Chow KM. Trimethylamine- $\mathrm{N}$-oxide as one hypothetical link for the relationship between intestinal microbiota and cancer-where we are and where shall we go? J Cancer. 2019;10(23):5874-82.

41. Cheng G, Li Y, Omoto Y, Wang Y, Berg T, Nord M, Vihko P, Warner M, Piao YS, Gustafsson JA. Differential regulation of estrogen receptor (ER) alpha and ERbeta in primate mammary gland. J Clin Endocrinol Metab. 2005;90(1):435-44.

42. Chiellini G, Erba P, Carnicelli V, Manfredi C, Frascarelli S, Ghelardoni S, Mariani G, Zucchi R. Distribution of exogenous [125I]-3-iodothyronamine in mouse in vivo: relationship with trace amine-associated receptors. J Endocrinol. 2012;213:223-30.

43. Choghakhori R, Abbasnezhad A, Amani R, Alipour M. Sex-related differences in clinical symptoms, quality of life, and biochemical factors in irritable bowel syndrome. Dig Dis Sci. 2017;62(6):1550-60.

44. Choghakhori R, Abbasnezhad A, Hasanvand A, Amani R. Inflammatory cytokines and oxidative stress biomarkers in irritable bowel syndrome: association with digestive symptoms and quality of life. Cytokine. 2017:93:34-433.

45. Chong PP, Chin VK, Looi CY, Wong WF, Madhavan P, Yong VC. The microbiome and irritable bowel syndrome - a review on the pathophysiology, current research and future therapy. Front Microbiol. 2019;10:1136.

46. Christian SL, Berry MD. Trace amine-associated receptors as novel therapeutic targets for immunomodulatory disorders. Front Pharmacol. 2018;9:680

47. Collins SM, Denou E, Verdu EF, Bercik P. The putative role of the intestinal microbiota in the irritable bowel syndrome. Dig Liver Dis. 2009;41(12):850-3.

48. Condliffe SB, Doolan CM, Harvey BJ. 17b-Oestradiol acutely regulates $\mathrm{Cl}$ secretion in rat distal colonic epithelium. J Physiol. 2001;530(1):47-544.

49. Corney R, Stanton R. Physical symptom severity, psychological and social dysfunction in a series of outpatients with irritable bowel syndrome. J Psychosom Res. 1990;34(5):483-91.

50. Costello EK, Lauber CL, Hamady M, Fierer N, Gordon JI, Knight R. Bacterial community variation in human body habitats across space and time. Science. 2009;326:1694-7.

51. Coton E, Coton M. Evidence of horizontal transfer as origin of strain to strain variation of the tyramine production trait in Lactobacillus brevis. Food Microbiol. 2009;26(1):52-7.

52. Craciun S, Balskus EP. Microbial conversion of choline to trimethylamine requires a glycyl radical enzyme. Proc Natl Acad Sci USA. 2012;109(52):21307-12.

53. Crouzet L, Gaultier E, Del'Homme C, Cartier C, Delmas E, Dapoigny M, Fioramonti J, Bernalier-Donadille A. The hypersensitivity to colonic distension of IBS patients can be transferred to rats through their fecal microbiota. Neurogastroenterol Motil. 2013;25(4):e272-282.

54. Crowell MD. Role of serotonin in the pathophysiology of the irritable bowel syndrome. Br J Pharmacol. 2004;141(8):1285-93.

55. Cuomo R, Andreozzi P, Zito FP, Passananti V, De Carlo G, Sarnelli G. Irritable bowel syndrome and food interaction. World I Gastroenterol. 2014;20(27):8837-45.

56. D'Andrea G, Terrazzino S, Fortin D, Farruggio A, Rinaldi L, Leon A. HPLC electrochemical detection of trace amines in human plasma and platelets and expression of mRNA transcripts of trace amine receptors in circulating leukocytes. Neurosci Lett. 2003;346(1-2):89-92.

57. Dainese R, Galliani E, De Lazzari F, Di Leo V, Naccarato R. Discrepancies between reported food intolerance and sensitization test findings in irritable bowel syndrome patients. Am J Gastroenterol. 1999;94(7):1892-7.

58. Dave M, Higgins PD, Middha S, Rioux KP. The human gut microbiome: current knowledge, challenges, and future directions. Transl Res. 2012;160(4):246-57.
59. De Preter $V$, Verbeke K. Metabolomics as a diagnostic tool in gastroenterology. World J Gastrointest Pharmacol Ther. 2013;4(4):97-107.

60. Del Rio B, Redruello B, Linares DM, Ladero V, Fernandez M, Martin MC, Ruas-Madiedo P, Alvarez MA. The dietary biogenic amines tyramine and histamine show synergistic toxicity towards intestinal cells in culture. Food Chem. 2017;218:249-55.

61. Dial EJ, Cooper C, Lichtenberger LM. Amino acid- and amine-induced gastrin release from isolated rat endocrine granules. Am J Physiol. 1991;260(2):G175-G181181.

62. Didari T, Mozaffari S, Nikfar S, Abdollahi M. Effectiveness of probiotics in irritable bowel syndrome: updated systematic review with meta-analysis. World J Gastroenterol. 2015;21(10):3072-84.

63. Dinter J, Muhlhaus J, Jacobi SF, Wienchol CL, Coster M, Meister J, Hoefig CS, Muller A, Kohrle J, Gruters A, Krude H, Mittag J, Schoneberg T, Kleinau G, Biebermann H. 3-iodothyronamine differentially modulates alpha-2A-adrenergic receptor-mediated signaling. J Mol Endocrinol. 2015;54(3):205-16.

64. Distrutti E, Monaldi L, Ricci P, Fiorucci S. Gut microbiota role in irritable bowel syndrome: new therapeutic strategies. World J Gastroenterol. 2016;22(7):2219-41.

65. Dlugos A, Childs E, Stuhr KL, Hillard CJ, de Wit H. Acute stress increases circulating anandamide and other $\mathrm{N}$-acylethanolamines in healthy humans. Neuropsychopharmacology. 2012;37(11):2416-27.

66. Dlugosz A, Winckler B, Lundin E, Zakikhany K, Sandstrom G, Ye W, Engstrand L, Lindberg G. No difference in small bowel microbiota between patients with irritable bowel syndrome and healthy controls. Sci Rep. 2015;5:8508.

67. Drossman DA, Toner BB, Whitehead WE, Diamant NE, Dalton CB, Duncan S, Emmott S, Proffitt V, Akman D, Frusciante K, Le T, Meyer K, Bradshaw B, Mikula K, Morris CB, Blackman CJ, Hu Y, Jia H, Li JZ, Koch GG, Bangdiwala SI. Cognitive-behavioral therapy versus education and desipramine versus placebo for moderate to severe functional bowel disorders. Gastroenterology. 2003;125(1):19-311.

68. Dunlop SP, Coleman NS, Blackshaw E, Perkins AC, Singh G, Marsden CA, Spiller RC. Abnormalities of 5-hydroxytryptamine metabolism in irritable bowel syndrome. Clin Gastroenterol Hepatol. 2005;3:349-57.

69. El-Salhy M, Gilja OH, Hatlebakk JG, Hausken T. Stomach antral endocrine cells in patients with irritable bowel syndrome. Int J Mol Med. 2014;34(4):967-74.

70. El-Salhy M, Hatlebakk JG, Hausken T. Possible role of peptide YY (PYY) in the pathophysiology of irritable bowel syndrome (IBS). Neuropeptides. 2020;79:101973.

71. Enck P, Mazurak N. Dysbiosis in functional bowel disorders. Ann Nutr Metab. 2018;72(4):296-306.

72. Endo Y, Shoji T, Fukudo S. Epidemiology of irritable bowel syndrome. Ann Gastroenterol. 2015;28:158-9.

73. Fayyaz M, Lackner JM. Serotonin receptor modulators in the treatment of irritable bowel syndrome. Ther Clin Risk Manag. 2008;4(1):41-8.

74. Fennema D, Phillips IR, Shephard EA. Trimethylamine and trimethylamine $\mathrm{N}$-oxide, a flavin-containing monooxygenase 3 (FMO3)-mediated host-microbiome metabolic axis implicated in health and disease. Drug Metab Dispos. 2016;44(11):1839-50.

75. Fernandez de Palencia P, Fernandez M, Mohedano ML, Ladero V, Quevedo C, Alvarez MA, Lopez P. Role of tyramine synthesis by foodborne Enterococcus durans in adaptation to the gastrointestinal tract environment. Appl Environ Microbiol. 2011;77(2):699-702.

76. Flak MB, Neves JF, Blumberg RS. Welcome to the microgenderome. Science. 2013;339:1044-5.

77. Florica-Howells E, Hen R, Gingrich J, Li Z, Gershon MD. 5-HT2A receptors: location and functional analysis in intestines of wild-type and 5-HT2A knockout mice. Am J Physiol Gastrointest Liver Physiol. 2002;282:G877-G893893.

78. Ford AC, Quigley EMM, Lacy BE, Lembo AJ, Saito YA, Schiller LR. Efficacy of prebiotics, probiotics, and synbiotics in irritable bowel syndrome and chronic idiopathic constipation: systematic review and meta-analysis. Am J Gastroenterol. 2014;109:1547-61.

79. Frohlich EE, Farzi A, Mayerhofer R, Reichmann F, Jacan A, Wagner B, Zinser E, Bordag N, Magnes C, Frohlich E, Kashofer K, Gorkiewicz G, Holzer P. Cognitive impairment by antibiotic-induced gut dysbiosis: analysis of gut microbiota-brain communication. Brain Behav Immun. 2016;56:140-55. 
80. Gainetdinov RR, Hoener MC, Berry MD. Trace amines and their receptors. Pharmacol Rev. 2018;70(3):549-620.

81. Gardini F, Martuscellib M, Carusob MC, Galganob F, Crudele MA, Favati F, Guerzoni ME, Suzzi G. Effects of pH, temperature and $\mathrm{NaCl}$ concentration on the growth kinetics, proteolytic activity and biogenic amine production of Enterococcus faecalis. Int J Food Microbiol. 2001;64:105-17.

82. Gardini F, Rossi F, Rizzotti L, Torriani S, Grazia L, Chiavari C, Coloretti F, Tabanelli G. Role of Streptococcus thermophilus PRI60 in histamine accumulation in cheese. Int Dairy J. 2012;27(1-2):71-6.

83. Gavaghan McKee CL, Wilson ID, Nicholson JK. Metabolic phenotyping of nude and normal (Alpk:ApfCD, C57BL10J) mice. J Proteome Res. 2006:5(2):378-84.

84. Gershon MD. 5-Hydroxytryptamine (serotonin) in the gastrointestinal tract. Curr Opin Endocrinol Diabetes Obes. 2013;20:14-211.

85. Gershon MD, Tack J. The serotonin signaling system: from basic understanding to drug development for functional GI disorders. Gastroenterology. 2007;132(1):397-414.

86. Gharbi Y, Fhoula I, Ruas-Madiedo P, Afef N, Boudabous A, Gueimonde M, Ouzari H-I. In-vitro characterization of potentially probiotic Lactobacillus strains isolated from human microbiota interaction with pathogenic bacteria and the enteric cell line HT29. Ann Microbiol. 2019;69:61-72.

87. Ghoshal UC, Park H, Gwee KA. Bugs and irritable bowel syndrome: the good, the bad and the ugly. J Gastroenterol Hepatol. 2010;25(2):244-51.

88. Gibson PR, Varney J, Malakar S, Muir JG. Food components and irritable bowel syndrome. Gastroenterology. 2015;148(6):1158-1174.e1154.

89. Glossmann HH, Lutz OMD. Torpor: the rise and fall of 3-monoiodothyronamine from brain to gut-from gut to brain? Front Endocrinol. 2017;8:118.

90. Gorinski N, Bijata M, Prasad S, Wirth A, Abdel Galil D, Zeug A, Bazovkina D, Kondaurova E, Kulikova E, Ilchibaeva T, Zareba-Koziol M, Papaleo F, Scheggia D, Kochlamazashvili G, Dityatev A, Smyth I, Krzystyniak A, Wlodarczyk J, Richter DW, Strekalova T, Sigrist S, Bang C, Hobuss L, Fiedler J, Thum T, Naumenko VS, Pandey G, Ponimaskin E. Attenuated palmitoylation of serotonin receptor 5-HT1A affects receptor function and contributes to depression-like behaviors. Nat Commun. 2019;10(1):3924.

91. Grabauskas G, Wu X, Gao J, Li J-Y, Turgeon DK, Owyang C. Prostaglandin $E 2$, produced by mast cells in colon tissues from patients with irritable bowel syndrome, contributes to visceral hypersensitivity in mice. Gastroenterology. 2020;158:2195-207.

92. Grimsby J, Toth M, Chen K, Kumazawa T, Klaidman L, Adams JD, Karoum F, Gal J, Shih JC. Increased stress response and $\beta$-phenylethylamine in MAOB-deficient mice. Nat Genet. 1997;17:206-10.

93. Halbreich U, Kahn LS. Role of estrogen in the aetiology and treatment of mood disorders. CNS Drugs. 2001;15(10):797-817.

94. Halpern M. Structure and function of the vomeronasal system: an update. Prog Neurobiol. 2003;70(3):245-318.

95. Heinken A, Khan MT, Paglia G, Rodionov DA, Harmsen HJ, Thiele I. Functional metabolic map of Faecalibacteriumprausnitzii, a beneficial human gut microbe. J Bacteriol. 2014;196(18):3289-302.

96. Heitkemper M, Carter E, Ameen V. Women with irritable bowel syndrome: differences in patients' and physicians' perceptions. Gastroenterol Nurs. 2002;25:192-200.

97. Heitkemper M, Jarrett M. Irritable bowel syndrome: does gender matter? J Psychosom Res. 2008;64(6):583-7.

98. Heitkemper MM, Jarrett M. Patterns of gastrointestinal and somatic symptoms across the menstrual cycle. Gastroenterology. 1992;102:505-13.

99. Hill C, Guarner F, Reid G, Gibson GR, Merenstein DJ, Pot B, Morelli L, Canani RB, Flint HJ, Salminen S, Calder PC, Sanders ME, Expert consensus document. The International Scientific Association for probiotics and prebiotics consensus statement on the scope and appropriate use of the term probiotic. Nat Rev Gastroenterol Hepatol. 2014;11(8):506-14.

100. Hoefig CS, Wuensch T, Rijntjes E, Lehmphul I, Daniel H, Schweizer U, Mittag J, Kohrle J. Biosynthesis of 3-iodothyronamine from T4 in murine intestinal tissue. Endocrinology. 2015;156(11):4356-64.

101. Hoefig CS, Zucchi R, Kohrle J. Thyronamines and derivatives: physiological relevance, pharmacological actions, and future research directions. Thyroid. 2016;26(12):1656-72.
102. Hoyles L, Jiménez-Pranteda ML, Chilloux J, Brial F, Myridakis A, Aranias T, Magnan C, Gibson GR, Sanderson JD, Nicholson JK, Gauguier D, McCartney AL, Dumas M-E. Metabolic retroconversion of trimethylamine $\mathrm{N}$-oxide and the gut microbiota. Microbiome. 2018;6:73.

103. Jacobs JP, Goudarzi M, Singh N, Tong M, McHardy IH, Ruegger P, Asadourian M, Moon BH, Ayson A, Borneman J, McGovern DP, Fornace AJ Jr, Braun J, Dubinsky M. A disease-associated microbial and metabolomics state in relatives of pediatric inflammatory bowel disease patients. Cell Mol Gastroenterol Hepatol. 2016;2(6):750-66.

104. Jeffery IB, Das A, O'Herlihy E, Coughlan S, Cisek K, Moore M, Bradley F, Carty T, Pradhan M, Dwibedi C, Shanahan F, O'Toole PW. Differences in fecal microbiomes and metabolomes of people with vs without irritable bowel syndrome and bile acid malabsorption. Gastroenterology. 2020;158(4):1016-28.

105. Jeffery IB, O'Toole PW, Ohman L, Claesson MJ, Deane J, Quigley EM, Simren M. An irritable bowel syndrome subtype defined by speciesspecific alterations in faecal microbiota. Gut. 2012;61(7):997-1006.

106. Jones RM, Mercante JW, Neish AS. Reactive oxygen production induced by the gut microbiota: pharmacotherapeutic implications. Curr Med Chem. 2012:19(10):1519-29.

107. Joosten HMLJ, Northolt MD. Detection, growth, and amine-producing capacity of Lactobacilli in cheese. Appl Environ Microbiol. 1989;55(9):2356-9.

108. Kalnins G, Kuka J, Grinberga S, Makrecka-Kuka M, Liepinsh E, Dambrova M, Tars K. Structure and function of CutC choline lyase from human microbiota bacterium Klebsiella pneumoniae. J Biol Chem. 2015;290(35):21732-40

109. Kane SV, Sable K, Hanauer SB. The menstrual cycle and its effect on inflammatory bowel disease and irritable bowel syndrome: a prevalence study. Am J Gastroenterol. 1998;93:1867-72.

110. Kano M, Muratsubaki T, Van Oudenhove L, Morishita J, Yoshizawa M, Kohno K, Yagihashi M, Tanaka Y, Mugikura S, Dupont P, Ly HG, Takase K, Kanazawa M, Fukudo S. Altered brain and gut responses to corticotropin-releasing hormone $(\mathrm{CRH})$ in patients with irritable bowel syndrome. Sci Rep. 2017;7(1):12425.

111. Kennedy PJ, Cryan JF, Quigley EM, Dinan TG, Clarke G. A sustained hypothalamic-pituitary-adrenal axis response to acute psychosocial stress in irritable bowel syndrome. Psychol Med. 2014;44(14):3123-34.

112. Kerlin P, Wong L. Breath hydrogen testing in bacterial overgrowth of the small intestine. Gastroenterology. 1988;95:982-8.

113. Kim D-Y, Camilleri M. Serotonin: a mediator of the brain-gut connection. Am J Gastroenterol. 2000:95(10):2698-709.

114. Klem F, Wadhwa A, Prokop L, Sundt WJ, Farrugia G, Camilleri M, Singh S, Grover M. Prevalence, risk factors, and outcomes of irritable bowel syndrome after infectious enteritis: a systematic review and meta-analysis. Gastroenterology. 2017;152(5):1042-54.

115. Koh A, De Vadder F, Kovatcheva-Datchary P, Backhed F. From Dietary Fiber to Host Physiology: Short-Chain Fatty Acids as Key Bacterial Metabolites. Cell. 2016;165(6):1332-455.

116. Koppel N, Maini Rekdal V, Balskus EP. Chemical transformation of xenobiotics by the human gut microbiota. Science. 2017;356(6344):eaag2770.

117. Kugaya A, Epperson CN, Zoghbi S, van Dyck CH, Hou Y, Fujita M, Staley JK, Garg PK, Seibyl JP, Innis RB. Increase in prefrontal cortex Serotonin2A receptors following estrogen treatment in postmenopausal women. Am J Psychiatry. 2003;160:1522-4.

118. Kumar S, Misra A, Ghoshal UC. Patients with irritable bowel syndrome exhale more hydrogen than healthy subjects in fasting state. J Neurogastroenterol Motil. 2010;16(3):299-305.

119. Kwa M, Plottel CS, Blaser MJ, Adams S. The intestinal microbiome and estrogen receptor-positive female breast cancer. J Natl Cancer Inst. 2016;108(8):djw029.

120. La Gioia F, Rizzotti L, Rossi F, Gardini F, Tabanelli G, Torriani S. Identification of a tyrosine decarboxylase gene (tdcA) in Streptococcus thermophilus 1TT45 and analysis of its expression and tyramine production in milk. Appl Environ Microbiol. 2011;77(3):1140-4.

121. Lacy BE, Patel NK. Rome criteria and a diagnostic approach to irritable bowel syndrome. J Clin Med. 2017;6(11):99.

122. Lauweryns JM, Van Ranst L. Immunocytochemical localization of aromatic L-amino acid decarboxylase in human, rat, and mouse 
bronchopulmonary and gastrointestinal endocrine cells. J Histochem Cytochem. 1998;36:1181-6.

123. Lazaridis N, Germanidis G. Current insights into the innate immune system dysfunction in irritable bowel syndrome. Ann Gastroenterol. 2018;31(2):171-87.

124. Lee BJ, Bak YT. Irritable bowel syndrome, gut microbiota and probiotics. J Neurogastroenterol Motil. 2011;17(3):252-66.

125. Lee KN, Lee OY. The role of mast cells in irritable bowel syndrome. Gastroenterol Res Pract. 2016;2016:2031480.

126. Liberles SD, Buck LB. A second class of chemosensory receptors in the olfactory epithelium. Nature. 2006;442(7103):645-50.

127. Lindemann L, Ebeling M, Kratochwil NA, Bunzow JR, Grandy DK, Hoener MC. Trace amine-associated receptors form structurally and functionally distinct subfamilies of novel $G$ protein-coupled receptors. Genomics. 2005;85(3):372-85.

128. Lopez-Siles M, Duncan SH, Garcia-Gil LJ, Martinez-Medina M. Faecalibacterium prausnitzii: from microbiology to diagnostics and prognostics. ISME J. 2017;11(4):841-52.

129. Lorencová E, Buñková L, Matoulková D, Dráb V, Pleva P, Kubáñ V, Buñka F. Production of biogenic amines by lactic acid bacteria and bifidobacteria isolated from dairy products and beer. Int J Food Sci Technol. 2012;47(10):2086-91.

130. Lozupone CA, Stombaugh J, Gonzalez A, Ackermann G, Wendel D, Vazquez-Baeza Y, Jansson JK, Gordon JI, Knight R. Meta-analyses of studies of the human microbiota. Genome Res. 2013;23(10):1704-14.

131. Lucas PM, Wolken WA, Claisse O, Lolkema JS, Lonvaud-Funel A. Histamine-producing pathway encoded on an unstable plasmid in Lactobacillus hilgardii 0006. Appl Environ Microbiol. 2005;71(3):1417-24.

132. Lundgren O. 5-Hydroxytryptamine, enterotoxins, and intestinal fluid secretion. Gastroenterology. 1998;115:1009-122.

133. Luqman A, Nega M, Nguyen MT, Ebner P, Gotz F. SadA-expressing Staphylococci in the human gut show increased cell adherence and internalization. Cell Rep. 2018;22(2):535-45.

134. Makker J, Chilimuri S, Bella JN. Genetic epidemiology of irritable bowel syndrome. World J Gastroenterol. 2015;21(40):11353-61.

135. Marcobal A, de las Rivas B, Landete JM, Tabera L, Muñoz R. Tyramine and phenylethylamine biosynthesis by food bacteria. Crit Rev Food Sci Nutr. 2012;52(5):448-67.

136. Marcobal A, de las Rivas B, Munoz R. First genetic characterization of a bacterial beta-phenylethylamine biosynthetic enzyme in Enterococcus faecium RM58. FEMS Microbiol Lett. 2006;258(1):144-9.

137. Marcobal A, Kashyap PC, Nelson TA, Aronov PA, Donia MS, Spormann A, Fischbach MA, Sonnenburg JL. A metabolomic view of how the human gut microbiota impacts the host metabolome using humanized and gnotobiotic mice. ISME J. 2013;7(10):1933-43.

138. Marcobal A, Martin-Alvarez PJ, Moreno-Arribas MV, Munoz R. A multifactorial design for studying factors influencing growth and tyramine production of the lactic acid bacteria Lactobacillusbrevis CECT 4669 and Enterococcus faecium BIFI-58. Res Microbiol. 2006;157(5):417-24.

139. Matsumoto M, Kibe R, Ooga T, Aiba Y, Sawaki E, Koga Y, Benno Y. Cerebral low-molecular metabolites influenced by intestinal microbiota: a pilot study. Front Syst Neurosci. 2013;7:9.

140. Mavrangelos C, Campaniello MA, Andrews JM, Bampton PA, Hughes PA. Longitudinal analysis indicates symptom severity influences immune profile in irritable bowel syndrome. Gut. 2017;67:398-9.

141. Mawe GM, Coates MD, Moses PL. Review article: intestinal serotonin signalling in irritable bowel syndrome. Aliment Pharmacol Ther. 2006;23(8):1067-76.

142. Mawe GM, Hoffman JM. Serotonin signalling in the gut-functions, dysfunctions and therapeutic targets. Nat Rev Gastroenterol Hepatol. 2013;10:473-86.

143. Mayer EA. Gut feelings: the emerging biology of gut-brain communication. Nat Rev Neurosci. 2011;12:453-66.

144. Mayer EA, Savidge T, Shulman RJ. Brain-gut microbiome interactions and functional bowel disorders. Gastroenterology. 2014;146(6):1500-12.

145. McCabe-Sellers BJ, Staggs CG, Bogle ML. Tyramine in foods and monoamine oxidase inhibitor drugs: a crossroad where medicine, nutrition, pharmacy, and food industry converge. J Food Compos Anal. 2006;19:S58-S65.
146. Meleine M Matricon J. Gender-related differences in irritable bowel syndrome: potential mechanisms of sex hormones. World J Gastroenterol. 2014:20(22):6725-43.

147. Mete R, Tulubas F, Oran M, Yilmaz A, Avci BA, Yildiz K, Turan CB, Gurel $A$. The role of oxidants and reactive nitrogen species in irritable bowel syndrome: a potential etiological explanation. Med Sci Monit. 2013;19:762-6.

148. Miller GM. The emerging role of trace amine-associated receptor 1 in the functional regulation of monoamine transporters and dopaminergic activity. J Neurochem. 2011;116(2):164-76.

149. Miquel S, Leclerc M, Martin R, Chain F, Lenoir M, Raguideau S, Hudault S, Bridonneau C, Northen T, Bowen B, Bermudez-Humaran LG, Sokol $H$, Thomas M, Langella P. Identification of metabolic signatures linked to anti-inflammatory effects of Faecalibacterium prausnitzii. mBio. 2015;6(2)

150. Mobley JA, Brueggemeier RW. Estrogen receptor-mediated regulation of oxidative stress and DNA damage in breast cancer. Carcinogenesis. 2004:25(1):3-9.

151. Moises HW, Waldmeier P, Beckmann H. Phenethylamine and Personality. In: Boulton AA, Bieck PR, Maitre L, Riederer P, editors. Neuropsychopharmacology of the trace amines. Clifton: Humana Press; 1985. p. 392.

152. Monsbakken KW, Vandvik PO, Farup PG. Perceived food intolerance in subjects with irritable bowel syndrome-etiology, prevalence and consequences. Eur J Clin Nutr. 2006;60(5):667-72.

153. Moracanin SV, Stefanovic S, Radicevic T, Borovic B, Djukic D. Production of biogenic amines by lactic acid bacteria isolated from uzicka sausages. Procedia Food Sci. 2015:5:308-11.

154. Moreno-Arribas V, Lonvaud-Funel A. Tyrosine decarboxylase activity of Lactobacillusbrevis IOEB 9809 isolated from wine and L. brevis ATCC 367. FEMS Microbiol Lett. 1999;180:55-60.

155. Moses-Kolko E. Widespread increases of cortical serotonin type $2 \mathrm{~A}$ receptor availability after hormone therapy in euthymic postmenopausal women. Fertil Steril. 2003;80(3):554-9.

156. Mozaffari S, Esmaily H, Rahimi R, Baeeri M, Sanei Y, Asadi-Shahmirzadi A, Salehi-Surmaghi M-H, Abdollah M. Effects of Hypericum perforatum extract on rat irritable bowel syndrome. Pharmacogn Mag. 2011;7(27):213-23.

157. Mulak A, Tache Y, Larauche M. Sex hormones in the modulation of irritable bowel syndrome. World J Gastroenterol. 2014;20(10):2433-48.

158. Navarro HA, Gilmour BP, Lewin AH. A rapid functional assay for the human trace amine-associated receptor 1 based on the mobilization of internal calcium. J Biomol Screen. 2006:11(6):688-93.

159. Neish AS. Microbes in gastrointestinal health and disease. Gastroenterology. 2009;136(1):65-80

160. Nelson DA, Tolbert MD, Singh SJ, Bost KL. Expression of neuronal trace amine-associated receptor (Taar) mRNAs in leukocytes. J Neuroimmunol. 2007;192:21-30.

161. Nishimura K, Utsumi K, Yuhara M, Fujitani Y, Iritani A. Identification of puberty-accelerating pheromones in male mouse urine. J Exp Zool. 1989;251(3):300-5.

162. Nobaek S, Johansson ML, Molin G, Ahrné S, Jeppsson B. Alteration of intestinal microflora is associated with reduction in abdominal bloating and pain in patients with irritable bowel syndrome. Am J Gastroenterol. 2000;95(5):1231-8.

163. Novotny MV. Pheromones, binding proteins and receptor responses in rodents. Biochem Soc Trans. 2003;31:117-22.

164. Nugent SG, Kumard D, Rampton S, Evans DF. Intestinal luminal pH in inflammatory bowel disease: possible determinants and implications for therapy with aminosalicylates and other drugs. Gut. 2001:48:571-7.

165. O'Mahony F, Harvey BJ. Sex and estrous cycle-dependent rapid protein kinase signaling actions of estrogen in distal colonic cells. Steroids. 2008;73(9-10):889-94.

166. O'Mahony L, McCarthy J, Kelly P, Hurley G, Luo F, Chen K, O'Sullivan GC, Kiely B, Collins JK, Shanahan F, Quigley EM. Lactobacillus and bifidobacterium in irritable bowel syndrome: symptom responses and relationship to cytokine profiles. Gastroenterology. 2005;128(3):541-51.

167. O'Malley D. Endocrine regulation of gut function - a role for glucagonlike peptide-1 in the pathophysiology of irritable bowel syndrome. Exp Physiol. 2019;104(1):3-10.

168. Ofir R, Tamir S, Khatib S, Vaya J. Inhibition of serotonin re-uptake by licorice constituents. J Mol Neurosci. 2003:20:135-40. 
169. Ostlund H, Keller E, Hurd YL. Estrogen receptor gene expression in relation to neuropsychiatric disorders. Ann N Y Acad Sci. 2003;1007:54-63.

170. Padhy SK, Sahoo S, Mahajan S, Sinha SK. Irritable bowel syndrome: is it "irritable brain" or "irritable bowel"? J Neurosci Rural Pract. 2015;6(4):568-77

171. Park JM, Choi MG, Cho YK, Lee IS, Kim JI, Kim SW, Chung IS. Functional gastrointestinal disorders diagnosed by Rome III questionnaire in Korea. J Neurogastroenterol Motil. 2011;17(3):279-86.

172. Pata C, Erdal E, Yazici K, Camdeviren H, Ozkaya M, Ulu O. Association of the $-1438 \mathrm{G} / \mathrm{A}$ and $102 \mathrm{~T} / \mathrm{C}$ polymorphism of the 5-Ht2A receptor gene with irritable bowel syndrome $5-\mathrm{Ht} 2 \mathrm{~A}$ Gene polymorphism in irritable bowel syndrome. 2004

173. Paul WE, Zhu J. How are $T(H) 2$-type immune responses initiated and amplified? Nat Rev Immunol. 2010;10(4):225-35.

174. Paulos MA, Tessel RE. Excretion of beta-phenethylamine is elevated in humans after profound stress. Science. 1982;215(4536):1127-9.

175. Pecins-Thompson M, Brown NA, Bethea CL. Regulation of serotonin re-uptake transporter mRNA expression by ovarian steroids in rhesus macaques. Mol Brain Res. 1998;53:120-9.

176. Pegg AE. Toxicity of polyamines and their metabolic products. Chem Res Toxicol. 2013;26(12):1782-800.

177. Pei Y, Asif-Malik A, Canales JJ. Trace amines and the trace amineassociated receptor 1: pharmacology, neurochemistry, and clinical implications. Front Neurosci. 2016;10:148.

178. Pereira Cl, Matos D, San Romao MV, Crespo MT. Dual role for the tyrosine decarboxylation pathway in Enterococcus faecium E17: response to an acid challenge and generation of a proton motive force. Appl Environ Microbiol. 2009;75(2):345-52.

179. Perez M, Calles-Enriquez M, Nes I, Martin MC, Fernandez M, Ladero V, Alvarez MA. Tyramine biosynthesis is transcriptionally induced at low $\mathrm{pH}$ and improves the fitness of Enterococcus faecalis in acidic environments. Appl Microbiol Biotechnol. 2015;99(8):3547-58.

180. Pessione E. Lactic acid bacteria contribution to gut microbiota complexity: lights and shadows. Front Cell Infect Microbiol. 2012;2:86

181. Pfanzagl B, Zevallos VF, Schuppan D, Pfragner R, Jensen-Jarolim E. Histamine causes influx via T-type voltage-gated calcium channels in an enterochromaffin tumor cell line: potential therapeutic target in adverse food reactions. Am J Physiol Gastrointest Liver Physiol. 2019:316(2):G291-G303.

182. Philips SR. B-Phenethylamines: a metabolically and pharmacology active amine. In: Mosnaim AD, Wolf ME, editors. Phenylethylamines: biological mechanisms and clinical aspects. Marcel Dekker Inc: New York; 1987. p. 113-138.

183. Plottel CS, Blaser MJ. Microbiome and malignancy. Cell Host Microbe. 2011;10(4):324-35

184. Pozuelo M, Panda S, Santiago A, Mendez S, Accarino A, Santos J, Guarner F, Azpiroz F, Manichanh C. Reduction of butyrate- and methane-producing microorganisms in patients with Irritable Bowel Syndrome. Sci Rep. 2015;5:12693.

185. Quigley EM. Do patients with functional gastrointestinal disorders have an altered gut flora? Ther Adv Gastroenterol. 2009;2(4):23-30.

186. Raab S, Wang H, Uhles S, Cole N, Alvarez-Sanchez R, Kunnecke B, Ullmer C, Matile H, Bedoucha M, Norcross RD, Ottaway-Parker N, Perez-Tilve D, Conde KK, Tschop MH, Hoener MC, Sewing S. Incretinlike effects of small molecule trace amine-associated receptor 1 agonists. Mol Metab. 2016;5(1):47-56.

187. Raote I, Bhattacharya A, Panicker MM. Serotonin 2A (5-HT2A) receptor function: ligand-dependent mechanisms and pathways. In: Chattopadhyay A, editor. Serotonin receptors in neurobiology. Boca Raton: CRC Press/Taylor \& Francis; 2007.

188. Rauscher-Gabernig E, Grossgut R, Bauer F, Paulsen P. Assessment of alimentary histamine exposure of consumers in Austria and development of tolerable levels in typical foods. Food Control. 2009;20(4):423-9.

189. Regard JB, Sato IT, Coughlin SR. Anatomical profiling of G proteincoupled receptor expression. Cell. 2008;135(3):561-71.

190. Ringel-Kulka T, Choi CH, Temas D, Kim A, Maier DM, Scott K, Galanko JA, Ringel Y. Altered colonic bacterial fermentation as a potential pathophysiological factor in irritable bowel syndrome. Am J Gastroenterol. 2015:110(9):1339-46.
191. Rizzetto L, Fava F, Tuohy KM, Selmi C. Connecting the immune system, systemic chronic inflammation and the gut microbiome: the role of sex. J Autoimmun. 2018:92:12-34.

192. Roager HM, Licht TR. Microbial tryptophan catabolites in health and disease. Nat Commun. 2018;9(1):3294.

193. Robles-Medranda C, Oleas O, Valero M, Puga-Tejada M, Soria-Alcívar M, Ospina J, Alvarado-Escobar H, Muñoz-Jurado G, Baquerizo-Burgos J, Pitanga-Lukashok H. Confocal laser endomicroscopy detects colonic inflammation in patients with irritable bowel syndrome: a prospective study. Endosc Int Open. 2020;08:E550-E55757.

194. Rodino-Janeiro BK, Vicario M, Alonso-Cotoner C, Pascua-Garcia R, Santos J. A review of microbiota and irritable bowel syndrome: future in therapies. Adv Ther. 2018;35(3):289-310.

195. Romano A, Ladero V, Alvarez MA, Lucas PM. Putrescine production via the ornithine decarboxylation pathway improves the acid stress survival of Lactobacillus brevis and is part of a horizontally transferred acid resistance locus. Int J Food Microbiol. 2014;175:14-9.

196. Rossi F, Gardini F, Rizzotti L, La Gioia F, Tabanelli G, Torriani S. Quantitative analysis of histidine decarboxylase gene (hdcA) transcription and histamine production by Streptococcus thermophilus PRI60 under conditions relevant to cheese making. Appl Environ Microbiol. 2011;77(8):2817-22.

197. Rothschild D, Weissbrod O, Barkan E, Kurilshikov A, Korem T, Zeevi D, Costea PI, Godneva A, Kalka IN, Bar N, Shilo S, Lador D, Vila AV, Zmora N, Pevsner-Fischer M, Israeli D, Kosower N, Malka G, Wolf BC, AvnitSagi T, Lotan-Pompan M, Weinberger A, Halpern Z, Carmi S, Fu J, Wijmenga C, Zhernakova A, Elinav E, Segal E. Environment dominates over host genetics in shaping human gut microbiota. Nature. 2018;555(7695):210-5.

198. Rowland I, Gibson G, Heinken A, Scott K, Swann J, Thiele I, Tuohy K. Gut microbiota functions: metabolism of nutrients and other food components. Eur J Nutr. 2018:57(1):1-24.

199. Roy-Byrne PP, Davidson KW, Kessler RC, Asmundson GJ, Goodwin RD, Kubzansky L, Lydiard RB, Massie MJ, Katon W, Laden SK, Stein MB. Anxiety disorders and comorbid medical illness. Gen Hosp Psychiatry. 2008;30(3):208-25.

200. Ruiz-Capillas C. Biogenic amines in meat and meat products. Crit Rev Food Sci Nutr. 2004:44(7-8):489-99.

201. Ruiz-Capillas C, Herrero AM. Impact of biogenic amines on food quality and safety. Foods. 2019;8(2):62.

202. Rutigliano G, Accorroni A, Zucchi R. The case for TAAR1 as a modulator of central nervous system function. Front Pharmacol. 2017;8:987.

203. Saba A, Chiellini G, Frascarelli S, Marchini M, Ghelardoni S, Raffaelli A, Tonacchera M, Vitti P, Scanlan TS, Zucchi R. Tissue distribution and cardiac metabolism of 3-iodothyronamine. Endocrinology. 2010;151:5063-73.

204. Salonen A, de Vos WM, Palva A. Gastrointestinal microbiota in irritable bowel syndrome: present state and perspectives. Microbiology. 2010;156(Pt 11):3205-15.

205. Santoru ML, Piras C, Murgia A, Palmas V, Camboni T, Liggi S, Ibba I, Lai MA, Orru S, Blois S, Loizedda AL, Griffin JL, Usai P, Caboni P, Atzori L, Manzin A. Cross sectional evaluation of the gut-microbiome metaboIome axis in an Italian cohort of IBD patients. Sci Rep. 2017;7(1):9523.

206. Sasaki Y, Hada R, Nakajima H, Fukuda S, Munakata A. Improved localizing method of radiopill in measurement of entire gastrointestinal pH Profiles: colonic luminal pH in normal subjects and patients with crohn's disease. Am J Gastroenterol. 1997;92(1):114-8.

207. Sathyanarayana Rao TS, Yeragani VK. Hypertensive crisis and cheese. Indian J Psychiatry. 2009;51(1):65-6.

208. Seeman MV. Psychopathology in women and men: focus on female hormones. Am J Psychiatry. 1997;154:1641-7.

209. Shi X, Walter NA, Harkness JH, Neve KA, Williams RW, Lu L, Belknap JK, Eshleman AJ, Phillips TJ, Janowsky A. Genetic polymorphisms affect mouse and human trace amine-associated receptor 1 function. PLoS ONE. 2016;11(3):e0152581.

210. Simren M, Barbara G, Flint HJ, Spiegel BM, Spiller RC, Vanner S, Verdu EF, Whorwell PJ, Zoetendal EG, Rome Foundation C. Intestinal microbiota in functional bowel disorders: a Rome foundation report. Gut. 2013;62(1):159-76.

211. Simren M, Mansson A, Langkilde AM, Svedlund J, Abrahamsson H, Bengtsson U, Bjornsson ES. Food-related gastrointestinal symptoms in the irritable bowel syndrome. Digestion. 2001;63(2):108-15. 
212. Smith NJ, Milligan G. Allostery at G protein-coupled receptor homoand heteromers: uncharted pharmacological landscapes. Pharmacol Rev. 2010;62:701-25.

213. Snoody AM, Heckathorn D, Tessel RE. Cold-restraint stress and urinary endogenous b-phenylethylamine excretion in rats. Pharmacol Biochem Behav. 1985;22:497-500.

214. Sriram U, Cenna JM, Haldar B, Fernandes NC, Razmpour R, Fan S, Ramirez SH, Potula R. Methamphetamine induces trace amine-associated receptor 1 (TAAR1) expression in human T lymphocytes: role in immunomodulation. J Leukoc Biol. 2016;99:213-23.

215. Sze JY, Victor M, Loer C, Shi Y, Ruvkun G. Food and metabolic signalling defects in a Caenorhabditis elegans serotonin-synthesis mutant. Nature. 2000:403:560-4.

216. Tan HP, Lebeck LK, Nehlsen-Cannarella SL. Regulatory role of cytokines in IgE-mediated allergy. J Leukoc Biol. 1992;52(1):115-8.

217. Tap J, Derrien M, Tornblom H, Brazeilles R, Cools-Portier S, Dore J, Storsrud S, Le Neve B, Ohman L, Simren M. Identification of an intestinal microbiota signature associated with severity of irritable bowel syndrome. Gastroenterology. 2017;152(1):111-123.e118.

218. Thomas ML, Xu X, Norfleet AM, Watson CS. The presence of functional estrogen receptors in intestinal epithelial cells. Endocrinology. 1993;132:426-30

219. Tokunaga A, Saika M, Senba E. 5-HT2A receptor subtype is involved in the thermal hyperalgesic mechanism of serotonin in the periphery. Pain. 1998;76:349-55.

220. Torriani S, Felis GE, Fracchetti F. Selection criteria and tools for malolactic starters development: an update. Ann Microbiol. 2010;61(1):33-9.

221. Turvill JL, Connor P, Farthing MJ. The inhibition of cholera toxin-induced 5-HT release by the 5-HT(3) receptor antagonist, granisetron, in the rat. Br J Pharmacol. 2000;130:1031-6.

222. Vannucchi MG, Evangelista S. Experimental models of irritable bowel syndrome and the role of the enteric neurotransmission. J Clin Med. 2018;7(1):4.

223. Venditti P, Napolitano G, Di Stefano L, Chiellini G, Zucchi R, Scanlan TS, Di Meo S. Effects of the thyroid hormone derivatives 3-iodothyronamine and thyronamine on rat liver oxidative capacity. Mol Cell Endocrinol. 2011;341(1-2):55-62.

224. Vernocchi P, Del Chierico F, Putignani L. Gut microbiota profiling: metabolomics based approach to unravel compounds affecting human health. Front Microbiol. 2016;7:1144.

225. Videlock EJ, Shih W, Adeyemo M, Mahurkar-Joshi S, Presson AP, Polytarchou C, Alberto M, Iliopoulos D, Mayer EA, Chang L. The effect of sex and irritable bowel syndrome on HPA axis response and peripheral glucocorticoid receptor expression. Psychoneuroendocrinology. 2016;69:67-766

226. Vieira-Coelho MA, Soares-da-Silva P. Dopamine formation, from its immediate precursor 3,4-dihydroxyphenylalanine, along the rat digestive tract. Fundam Clin Pharmacol. 1993;7:235-43.

227. Wallrabenstein I, Kuklan J, Weber L, Zborala S, Werner M, Altmuller J, Becker C, Schmidt A, Hatt H, Hummel T, Gisselmann G. Human trace amine-associated receptor TAAR5 can be activated by trimethylamine. PLoS ONE. 2013;8(2):e54950.

228. Wasik AM, Millan MJ, Scanlan T, Barnes NM, Gordon J. Evidence for functional trace amine associated receptor-1 in normal and malignant B cells. Leuk Res. 2012;36(2):245-9.

229. Watts SW. Activation of the mitogen-activated protein kinase pathway via the 5-HT2A receptor. Ann N Y Acad Sci. 1998;861:162-8.

230. Whitehead WE, Cheskin LJ, Heller BR. Evidence for exacerbation of irritable bowel syndrome during menses. Gastroenterology. 1990;98:1485-9.

231. Wikoff WR, Anfora AT, Liu J, Schultz PG, Lesley SA, Peters EC, Siuzdak $G$. Metabolomics analysis reveals large effects of gut microflora on mammalian blood metabolites. Proc Natl Acad Sci USA. 2009;106(10):3698-703.

232. Williams BB, Van Benschoten AH, Cimermancic P, Donia MS, Zimmermann M, Taketani M, Ishihara A, Kashyap PC, Fraser JS, Fischbach MA. Discovery and characterization of gut microbiota decarboxylases that can produce the neurotransmitter tryptamine. Cell Host Microbe. 2014;16(4):495-503.
233. Wilson A, Teft WA, Morse BL, Choi YH, Woolsey S, DeGorter MK, Hegele RA, Tirona RG, Kim RB. Trimethylamine-N-oxide: a novel biomarker for the identification of inflammatory bowel disease. Dig Dis Sci. 2015;60(12):3620-30.

234. Wissink S, van der Burg B, Katzenellenbogen BS, van der Saag PT. Synergistic activation of the serotonin-1A receptor by nuclear factor-?B and estrogen. Mol Endocrinol. 2001;15(4):543-52.

235. Wlodarska M, Kostic AD, Xavier RJ. An integrative view of microbiomehost interactions in inflammatory bowel diseases. Cell Host Microbe. 2015;17(5):577-91.

236. Wöhrl S, Hemmer W, Focke M, Rappersberger K, Jarisch R. Histamine intolerance-like symptoms in healthy volunteers after oral provocation with liquid histamine. Allergy Asthma Proc. 2004;25:305-11.

237. Wolinsky TD, Swanson CJ, Smith KE, Zhong H, Borowsky B, Seeman P, Branchek T, Gerald CP. The trace amine 1 receptor knockout mouse: an animal model with relevance to schizophrenia. Genes Brain Behav. 2007;6(7):628-39.

238. Wouters MM, Dafne Balemans D, Van Wanrooy S, James Dooley J, Cibert-Goto V, Alpizar YA, Valdez-Morales EE, Nasser Y, Van Veldhoven PP, Vanbrabant W, Van der Merwe $S$, Mols $R$, Ghesquière B, Cirillo C, Kortekaas I, Carmeliet P, Peetermans WE, Vermeire S, Rutgeerts P, Augustijns P, Hellings PW, Belmans A, Vanner S, Bulmer DC, Talavera K, Vanden Berghe P, Liston A, Boeckxstaens GE. Histamine receptor H1-mediated sensitization of TRPV1 mediates visceral hypersensitivity and symptoms in patients with irritable bowel syndrome. Gastroenterology. 2016;150:875-87.

239. Yang $X$, Guo $Y$, He J, Zhang F, Sun $X$, Yang S, Dong H. Estrogen and estrogen receptors in the modulation of gastrointestinal epithelial secretion. Oncotarget. 2017:8(57):97683-92.

240. Yap IKS, Li JV, Saric J, Martin F-P, Davies H, Wang Y, Wilson ID, Nicholson JK, Utzinger J, Marchesi JR, Holmes E. Metabonomic and microbiological analysis of the dynamic effect of vancomycin-induced gut microbiota modification in the mouse. J Proteome Res. 2008;7(9):3718-28.

241. Young E, Korszun A. Sex, trauma, stress hormones and depression. Mol Psychiatry. 2010;15(1):23-8.

242. Yu LM, Zhao KJ, Wang SS, Wang X, Lu B. Gas chromatography/mass spectrometry based metabolomic study in a murine model of irritable bowel syndrome. World J Gastroenterol. 2018;24(8):894-904.

243. Yu Q, Liu X, Huang H, Zheng X, Pan X, Fang J, Meng L, Zhou C, Zhang X, Li Z, Zou D. Mass spectrometry-based metabolomics for irritable bowel syndrome biomarkers. Ther Adv Gastroenterol. 2019; 12.

244. Zamani MJ, Sharifzadeh M, Rezaie A, Mashayekhi F, Abdollahi M. Effects of sildenafil on rat irritable bowel syndrome. Therapy. 2005;2(2):237-42.

245. Zhang J, Pacifico R, Cawley D, Feinstein P, Bozza T. Ultrasensitive detection of amines by a trace amine-associated receptor. J Neurosci. 2013;33:3228-399.

246. Zhang LS, Davies SS. Microbial metabolism of dietary components to bioactive metabolites: opportunities for new therapeutic interventions Genome Med. 2016;8(1):46.

247. Zhu S, Liu S, Li H, Zhang Z, Zhang Q, Chen L, Zhao Y, Chen Y, Gu J, Min $L$, Zhang $S$. Identification of gut microbiota and metabolites signature in patients with irritable bowel syndrome. Front Cell Infect Microbiol. 2019:9:346.

248. Zhu Y, Jameson E, Crosatti M, Schafer H, Rajakumar K, Bugg TD, Chen Y. Carnitine metabolism to trimethylamine by an unusual Riesketype oxygenase from human microbiota. Proc Natl Acad Sci USA. 2014;111(11):4268-73.

249. Zucchi R, Accarino A, Chiellini G. Update on 3-iodothyronamine and its neurological and metabolic actions. Front Physiol. 2014;5:1-12.

250. Zucchi R, Chiellini G, Scanlan TS, Grandy DK. Trace amine-associated receptors and their ligands. Br J Pharmacol. 2006;149:967-78.

\section{Publisher's Note}

Springer Nature remains neutral with regard to jurisdictional claims in published maps and institutional affiliations. 